OECDpublishing

\title{
COVID-19 AND FOOD
} SYSTEMS:

SHORT- AND LONG-TERM IMPACTS

OECD FOOD, AGRICULTURE AND FISHERIES

\section{PAPER}

JULY $2021 \mathbf{n}^{\circ} \mathbf{1 6 6}$ 


\section{OECD TRADE AND AGRICULTURE DIRECTORATE}

\section{COVID-19 and Food Systems: Short- and Long-Term Impacts}

The COVID-19 pandemic placed unprecedented short-term stresses on food supply chains around the world. However, rapid responses by both private-sector actors and policy makers mostly managed to prevent severe disruptions. Yet, even before the outbreak of COVID-19, food systems were faced with a formidable "triple challenge" of simultaneously providing food security and nutrition to a growing global population, ensuring the livelihoods of millions of people working along the food chain from farm to fork, and ensuring the environmental sustainability of the sector. This paper discusses the stresses COVID-19 created in food supply chains and the remarkable resilience these supply chains have demonstrated in high-income countries, as well as specific impacts in the fisheries and aquaculture sectors and the importance of transparency in avoiding a COVID-19 induced food crisis. The paper concludes by discussing the long-term challenges for food systems, arguing that the unanticipated shock of COVID-19 strengthens the case for shifting from 'business as usual' policies to a more forward looking policy package for food systems.

Key words: Supply chain resilience, lockdown, stockpiling, transparency, fisheries, aquaculture, food security, nutrition, livelihoods, sustainability

JEL codes: L66, L81, L83, L91, Q17, Q18, Q22 


\section{Table of contents}

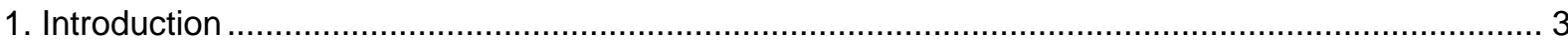

2. Food supply chains and COVID-19: Impacts and policy lessons................................................ 3

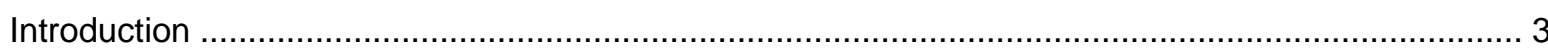

COVID-19 has placed unprecedented stresses on food supply chains ...................................... 4

Yet food supply chains in high-income countries were remarkably resilient ................................. 9

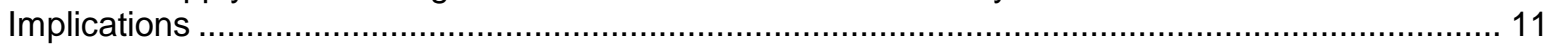

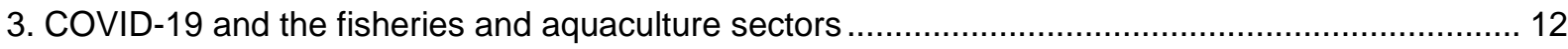

Impacts of COVID-19 on the fisheries and aquaculture sectors ................................................. 12

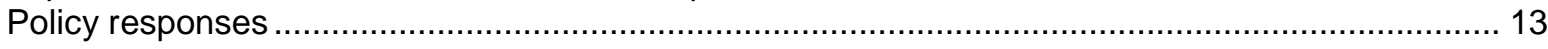

4. The role of transparency in avoiding a COVID-19 induced food crisis........................................ 16

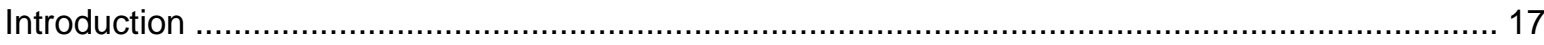

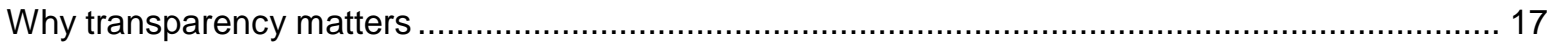

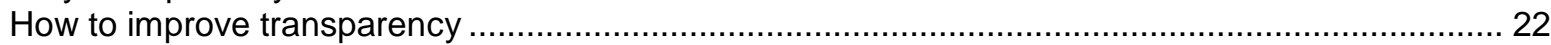

Continued investment in transparency and policy co-ordination is essential ................................. 24

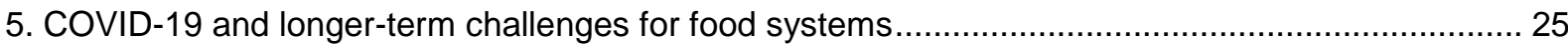

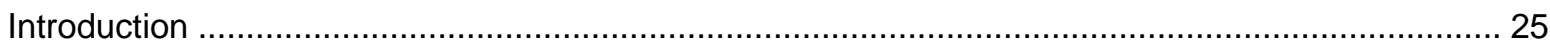

Food systems have made remarkable achievements, but much more needs to be done ............... 25

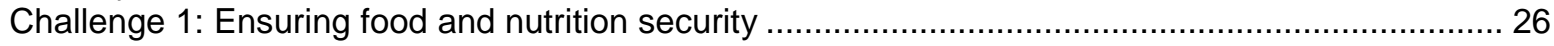

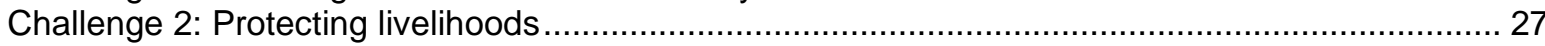

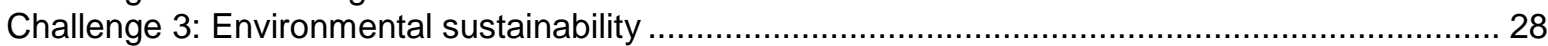

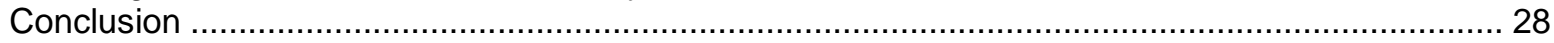

\section{Figures}

Figure 1. Restaurant reservations collapsed in 2020 as COVID-19 gathered pace 8

Figure 2. Retail food demand soared as consumers stockpiled, and has remained high

Figure 3. Maize, rice, soybeans and wheat price indices (daily) 19

Figure 4. Production, stocks and utilisation of maize, rice, soybeans and wheat 20

Figure 5. Export restrictions imposed on staple crops in response to the Covid-19 outbreak 22

\section{Tables}

Table 1. Public stock distribution by AMIS countries in response to the COVID-19 outbreak 18

Table 2. Timeline of export restriction decisions on rice in Viet Nam and grains in Russia 


\section{Introduction}

The COVID-19 pandemic has placed unprecedented short-term stresses on food supply chains around the world. Initially it was unclear to what extent food supply chains would be able to cope with these stresses; however, rapid responses by private-sector actors and policy makers mostly managed to prevent severe disruptions, in part thanks to transparency and a commitment to open trade in agri-food products.

Even before the outbreak of COVID-19, food systems were faced with a formidable "triple challenge" of simultaneously providing food security and nutrition to a growing global population, ensuring the livelihoods of millions of people working along the food chain from farm to fork, and ensuring the environmental sustainability of the sector. These long-term challenges require effective policy responses.

This document brings together insights from OECD work on COVID-19. The next section presents an overview of the stresses COVID-19 created in food supply chains, and the remarkable resilience these supply chains have demonstrated in high-income countries. The third section discusses in more detail the impact of COVID-19 in the fisheries and aquaculture sectors, as well as policy implications. The fourth section then highlights the importance of transparency in avoiding a COVID-19 induced food crisis, using the example of the Agricultural Market Information System (AMIS). The final section discusses the longterm challenges for food systems, arguing that the unanticipated shock of COVID-19 strengthens the case for shifting from "business as usual" policies to a more forward-looking policy package for food systems.

The material in this document was originally published on the OECD website as part of the series of policy briefs on COVID-19:

- Food Supply Chains and COVID-19: Impacts and Policy Lessons

- Fisheries, Aquaculture and COVID-19: Issues and Policy Responses

- The Role of Transparency in Avoiding A COVID-19 Induced Food Crisis

- COVID-19 and global Food Systems

\section{Food supply chains and COVID-19: Impacts and policy lessons}

The COVID-19 pandemic has placed unprecedented stresses on food supply chains, with bottlenecks in farm labour, processing, transport and logistics, as well as momentous shifts in demand. Most of these disruptions are a result of policies adopted to contain the spread of the virus. Food supply chains have demonstrated a remarkable resilience in the face of these stresses. Grocery store shelves have been replenished over time, as stockpiling behaviour disappeared and as supply chains responded to increased demand. Long lines at borders shrank quickly in response to policies to alleviate unnecessary restrictions. While the impacts of COVID-19 are still unfolding, experience so far shows the importance of an open and predictable international trade environment to ensure food can move to where it is needed. The biggest risk for food security is not with food availability but with consumers' access to food: safety nets are essential to avoid an increase in hunger and food insecurity.

\section{Introduction}

The COVID-19 pandemic introduced unexpected stresses on food systems, creating many immediate challenges. Yet what is remarkable is the speed with which supply chain actors were able to reorganise themselves to ensure the continued availability of food, at least in the developed world. Some bottlenecks persisted longer, and there is still a risk of new disruptions as COVID-19 continues to circulate. But the rapid response of food supply chains has underscored the importance of an open and predictable international trading environment, which allows firms to tap into new sources of supply when existing 
sources are compromised. Policy makers have also mostly avoided the mistakes made during the food price crisis of 2007-8, and have taken a range of other steps which have helped ensure the continued functioning of food supply chains.

This section reviews what was known about the impact of COVID-19 on food supply chains in the short run (i.e. the first few months of 2020). Reflecting the immediate concerns in the initial period of the crisis, the focus here is on food availability and consumers' access to food in OECD countries, and not on other important aspects, such as livelihoods of farmers and other supply chain actors, and environmental and health implications.

\section{COVID-19 has placed unprecedented stresses on food supply chains}

COVID-19 has imposed shocks on all segments of food supply chains, simultaneously affecting farm production, food processing, transport and logistics, and final demand. Not all sectors and products were equally affected and different products have experienced disruptions at different stages of the supply chain.

\section{Farm production faced bottlenecks for some inputs}

Farm production was affected by bottlenecks for inputs, most notably labour. Some farm sectors are more dependent on (seasonal) labour than others: fruits and vegetables are more labour-intensive, while cereals and oilseeds typically require less labour. Limits on the mobility of people reduced the availability of seasonal workers for planting and harvesting in the fruit and vegetable sector in many countries. ${ }^{1}$

In addition to farm labour, other important inputs are seed, pesticides, fertilisers, and energy. While seed shortages eventually turned out not to be a major problem, there was a risk of disruption (see Box 1 for a discussion of the seed sector). Concerns were also initially voiced regarding the availability of pesticides, for which the People's Republic of China (hereafter (China") is a major supplier. ${ }^{2}$ As China emerged from lockdown, these concerns appear to have waned. Supplies of fertilisers and energy were relatively less disrupted. Global availability of fertilisers was not a bottleneck, although local disruptions occurred because of transport difficulties. ${ }^{3}$

\footnotetext{
${ }^{1}$ For a detailed discussion of disruptions in the fruit and vegetables sector, see OECD Scheme for the Application of International Standards for Fruit and Vegetables, "Preliminary Report: Evaluation of the Impact of the Coronavirus (COVID-19) on Fruit and Vegetables Trade", 11 May 2020, https://www.oecd.org/agriculture/fruit-vegetables/oecdcovid-19-impact-on-fruit-and-vegetables-trade.pdf (TAD/CA/FVS/WD(2020)1/REV7).

2 See for India, https://www.thehindu.com/business/pesticide-sector-hit-by-input-issues/article31043301.ece; for Brazil: https://www.reuters.com/article/brazil-china-pesticides/brazil-farm-sector-frets-over-possible-china-pesticidesupply-disruptions-idUSL1N2B42XI. Other analysts disputed the vulnerability of Brazil's agriculture to disruptions of herbicide supply chains, however: see Rabobank, "Covid-19 Casts Shadow Over Fertiliser and Crop Protection Supply Chains", April 2020, https://research.rabobank.com/far/en/sectors/farm-inputs/covid-19-casts-shadow-over-fertiliserand-crop-protection-supply-chains.html;

${ }^{3}$ Data on energy and fertiliser prices are provided by the monthly AMIS Market Monitor, available at www.amisoutlook.org.
} 


\section{Box 1. COVID-19 and the seed sector}

The seed sector is highly globalised, and seed can travel through several countries for multiplication, production, processing and packaging. Most seed needed for the March, April and May 2020 sowing period (spring crops in the northern hemisphere, such as maize, soybean, and spring wheat; and autumn crops in the southern hemisphere - see Figure 3 ) had arrived before travel restrictions were put in place, but for some time it was unclear whether seed for the next growing seasons would arrive in time. Seed is also often transported by air, a mode of transport which continues to be severely disrupted (as discussed earlier). In addition, the seed sector was also affected by farm labour shortages and impediments to the work of seed certification staff due to stringent health measures.

Both public and private actors in the global seed sector undertook action to make sure seed production and trade would continue to operate. Many countries classified agriculture as an "essential" industry, which allowed seed certification staff and companies to continue operating while obeying social distancing rules. The OECD Seed Schemes has been working alongside its member countries and other international organizations to support the seed sector. ${ }^{1}$ Communication has helped to share best practices, while harmonisation of measures between countries has smoothed processes. A number of National Designated Authorities (NDAs) held weekly up-date meetings and continue to be in regular contact with industry, either directly or through associations such as the International Seed Federation (ISF) and World Farmers Organisation (WFO). Regional bodies such as MERCOSUR and the EU helped to develop co-ordinated strategies that facilitate trade. Even those countries that do not have a strong seed production sector acknowledged the important role that other seed producing countries play, and were supportive of flexible solutions within the current regulatory framework or temporary derogation of Rules and Regulations to facilitate international seed trade.

1. The OECD Seed Schemes have been certifying the varietal identity and purity of seed lots since the 1960 s. The Schemes facilitate the movement of high quality agricultural seeds across borders by harmonising certification standards and procedures. In 2020, 61 countries (both developed and developing) participated in the OECD Seed Schemes.

Source: OECD (2020), Policy responses to COVID-19 in the seed sector.

\section{Processing was disrupted by labour shortages and shutdowns}

COVID-19 led to disruptions in food processing industries, which were affected by rules on social distancing, by labour shortages due to illness, and by lockdown measures to contain the spread of the virus. In confined spaces such as packing plants for fruits and vegetables or meat processing facilities, necessary social distancing measures reduced the efficiency of operations. Many firms reported high rates of worker absences; for example, staff availability was reduced by up to $30 \%$ in French meat processing facilities in the regions of the country worst hit by COVID-19.4

COVID-19 clusters were found in meat processing plants in various countries. ${ }^{5}$ Employees often work in close proximity to each other, making it more difficult to respect physical distancing requirements. In some cases, workers also live together in overcrowded conditions, which further facilitated the spread of the virus. ${ }^{6}$ Meat processing appeared to be more sensitive than other types of food processing in part because of the labour intensive nature of operations. By contrast, grain handling and processing is highly automated and less labour intensive, and did not experience the same disruptions as the meat processing sector.

\footnotetext{
${ }^{4}$ See https://www.processalimentaire.com/vie-des-iaa/covid-19-la-filiere-viande-sous-tension?sso=1590405164.

${ }^{5}$ See https://www.wired.com/story/why-meatpacking-plants-have-become-covid-19-hot-spots/ and https://www.lemonde.fr/planete/article/2020/05/18/coronavirus-pourquoi-des-foyers-d-infection-apparaissent-ilsdans-des-abattoirs 6040056 3244.html.

6 See https://www.euractiv.com/section/agriculture-food/news/coronavirus-outbreak-exposing-vulnerabilities-in-theeu-meat-sector/.
} 
Many meat-processing plants shut down or were forced to operate at reduced capacity. In the United States, cattle and pig slaughter fell by about $40 \%$ in April 2020 compared to the same period in 2019. Low demand from meat processors left producers in North America with unsold mature animals, and producers had to resort to euthanizing animals to prevent overcrowding, particularly for pigs. ${ }^{7}$ In Europe, such drastic measures were not necessary. ${ }^{8}$ The effects of meat processing plant closures may have been especially pronounced in North America due to the concentrated nature of the industry; in the United States, almost $60 \%$ of pork processing capacity comes from just 15 plants. $^{9}$

\section{Some modes of transport were affected more than others}

Bottlenecks in transport and logistics disrupted the movement of products along supply chains. Broadly speaking, agricultural and food products are transported using three main modes of transport: bulk (ships and barges); containers (by boat, rail or truck) and other road transport; and air freight. Different products use different modes of transport: cereals and oilseeds, for example, are typically shipped in bulk; meat and dairy products are often shipped in refrigerated containers and trucks; and perishable products with a high value-to-weight ratio are transported by air in the "bellies" of passenger planes.

The impact of COVID-19 on these transport modes varied considerably. ${ }^{10}$ Bulk shipments did not see any major COVID-related disruptions, and prices for bulk freight were actually near multi-year lows during the first months of the COVID-19 crisis. ${ }^{11}$ However, airfreight was severely disrupted. Global air cargo capacity in the week of 10 to 16 May 2020 was 26\% lower than during the same period in 2019, with the largest decline in capacity on routes between Europe and Latin America (with declines of more than $80 \%$ ). The disruption was caused by the steep decline in passenger air travel, which normally accounts for the majority of air cargo capacity. ${ }^{12}$ Disruptions to container and truck transport fell somewhere in-between; the number of container ships in the first few months of 2020 was below normal due to COVID-19 restrictions such as limitations on crew changes, additional screening, mandatory quarantines, and reduced demand. ${ }^{13}$ Commercial road transport in April 2020 was about 20\% lower than usual in Canada and the United States. ${ }^{14}$ In Europe, truck traffic initially fell by more than $50 \%$ in Spain, $46 \%$ in France and $37 \%$ in Italy, although it subsequently recovered. In mid-April 2020, the total distance driven by trucks in Europe was $24 \%$ below normal. ${ }^{15}$

\footnotetext{
7 See, for example, https://www.foxbusiness.com/markets/farmers-euthanize-10-million-pigs-coronavirus for the United States and https://ici.radio-canada.ca/nouvelle/1698646/covid-porcs-euthanasie-quebec-abattoirs-olymel for Canada.

8 See https://www.euractiv.com/section/agriculture-food/news/coronavirus-outbreak-exposing-vulnerabilities-in-theeu-meat-sectorl.
}

9 See Jayson Lusk, "These 15 plants slaughter $59 \%$ of all hogs in the US", 9 April 2020, http://jaysonlusk.com/blog/2020/4/9/these-15-plants-slaughter-59-of-all-hogs-in-the-us.

${ }^{10}$ See Schmidhuber and Qiao, "Comparing Crises: Great Lockdown versus Great Recession", FAO Publicaitons, Rome, https://doi.org/10.4060/ca8833en.

${ }^{11}$ Over the subsequent months, as the global economy started to recover, bulk freight rates increased. For example, in May 2021 the Baltic Dry Index (a commonly used indicator of bulk freight rates) reached an 11-year high, while the IGC Grains and Oilseeds Freight Index had increased more than 150\% year on year. For information on developments in dry bulk freight markets and their potential effects on food prices, see the monthly AMIS Market Monitor, available at www.amis-outlook.org.

12 See Accenture, "COVID-19: Impact on air cargo capacity", 21 May 2020, https://www.accenture.com/usen/insights/travel/coronavirus-air-cargo-capacity.

13 See Inga Heiland and Karen-Helene Ulltveit-Moe, "An unintended crisis: COVID-19 restrictions hit sea transportation," 17 May 2020, https://voxeu.org/article/covid-19-restrictions-hit-sea-transportation.

14 See GeoTab, "The impact of COVID-19 on commercial transportation and trade activity", 12 May 2020, https://www.geotab.com/blog/impact-of-covid-19/.

15 See Sixfold.com, "Covid impact on logistics - share of idling trucks almost triples", 22 April 2020, https://sixfold.com/news/covid-impact-on-logistics-share-of-idling-trucks-almost-triples. 
Transport and logistics problems thus were most pronounced for perishable high-value products, such as fruits and vegetables. The fruits and vegetables sector was also affected by quarantine measures and delays in border inspections (including as the number of import/export inspectors was reduced by illness and social distancing requirements). ${ }^{16}$ By contrast, cereal supplies did not face major disruptions: bulk transport was less affected, and cereals can be loaded, shipped and handled with minimal labour input. ${ }^{17}$

\section{Consumer demand saw rapid and unprecedented shifts}

COVID-19 led to a drastic shift in consumer demand away from restaurants, food service and other types of "food away from home" towards food consumed at home, requiring important changes in the way food supply chains operate. As the COVID-19 pandemic gathered pace, sales of food away from home (consumed in hotels, restaurants, catering and cafés) collapsed. Restaurant reservations declined sharply in early March 2020 and fell to practically zero as countries went into the first of a series of lockdowns. ${ }^{18}$

At the same time, retail demand for food soared. Sales of frozen and packaged foods in particular increased dramatically: at their peak in the second half of March 2020, weekly sales of frozen foods were $63 \%$ higher than the year before in France, while sales of packaged foods were $56 \%$ higher year-on-year in Germany. Similar demand spikes were seen in other countries. Following this initial spike, retail demand for fresh, frozen or packaged foods has remained about $15-20 \%$ higher than usual. ${ }^{19}$

The impact of this shift in demand was considerable. In the United States, for instance, the "food away from home" sector normally accounts for $10 \%$ of the consumption of fruits, $32 \%$ of vegetables, $25 \%$ of dairy, $31 \%$ of cereals, and $33 \%$ of protein foods (a category which includes among other things meat, seafood, and eggs). ${ }^{20}$ Across most countries, the sector accounts for at least $25 \%$ to $30 \%$ of total sales of fresh fruit and vegetables. ${ }^{21}$ Shifting these volumes to the retail sector was not easy. In addition to logistical challenges, households' consumption patterns at home are different from those away from home. For example, food away from home tends to use more cheese (e.g. as toppings on pizza) and more expensive meat cuts (e.g. steaks vs minced meat at home). Even where similar products are consumed, products normally sold to restaurants and foodservice operations cannot always be sold to retailers without incurring extra costs. For example, while the foodservice industry buys large blocks of cheese, much smaller packages are needed for retail sales. ${ }^{22}$ Retailers may also have different quality expectations or other extra requirements. Finally, hotels and restaurants can be important contributors to food banks, and their closure reduced supply to these outlets at a time when demand for their services was increasing.

\footnotetext{
${ }^{16}$ See OECD Scheme for the Application of International Standards for Fruit and Vegetables, "Preliminary Report: Evaluation of the Impact of the Coronavirus (COVID-19) on Fruit and Vegetables Trade", 11 May 2020, https://www.oecd.org/agriculture/fruit-vegetables/oecd-covid-19-impact-on-fruit-and-vegetables-trade.pdf (TAD/CA/FVS/WD(2020)1/REV7).

${ }^{17}$ See AMIS Market Monitor No. 78 (May 2020), www.amis-outlook.org.

${ }^{18}$ See OpenTable.com, "The state of the restaurant industry", https://www.opentable.com/state-of-industry.

19 See IRI and Boston Consulting Group, "Consumer Spending Tracker for Measured Channels", 15 May 2020 , https://www.iriworldwide.com/IRI/media/Library/2020-05-15-IRI-BCG-COVID-Global-Consumer-Spend-Tracker.pdf.
}

20 See United States Department of Agriculture, Economic Research Service, "Average daily intake of food by food source and demographic characteristics, 2007-10", https://www.ers.usda.gov/data-products/food-consumption-andnutrient-intakes/.

${ }^{21}$ See OECD Scheme for the Application of International Standards for Fruit and Vegetables, "Preliminary Report: Evaluation of the Impact of the Coronavirus (COVID-19) on Fruit and Vegetables Trade", 11 May 2020 , https://www.oecd.org/agriculture/fruit-vegetables/oecd-covid-19-impact-on-fruit-and-vegetables-trade.pdf (TAD/CA/FVS/WD(2020)1/REV7).

22 See "Dairy outlook: COVID-19 lockdowns impact cheese and butter", 8 April 2020, https://www.foodprocessing.com.au/content/business-solutions/news/dairy-outlook-covid-19-lockdowns-impactcheese-and-butter-882083603; and Ben Laine, "For dairy, COVID-19 will have three waves," 22 April 2020, https://hoards.com/article-27711-for-dairy-covid-19-will-have-three-waves.html. 
Figure 1. Restaurant reservations collapsed in 2020 as COVID-19 gathered pace

Percentage change in daily restaurant reservations compared to 2019

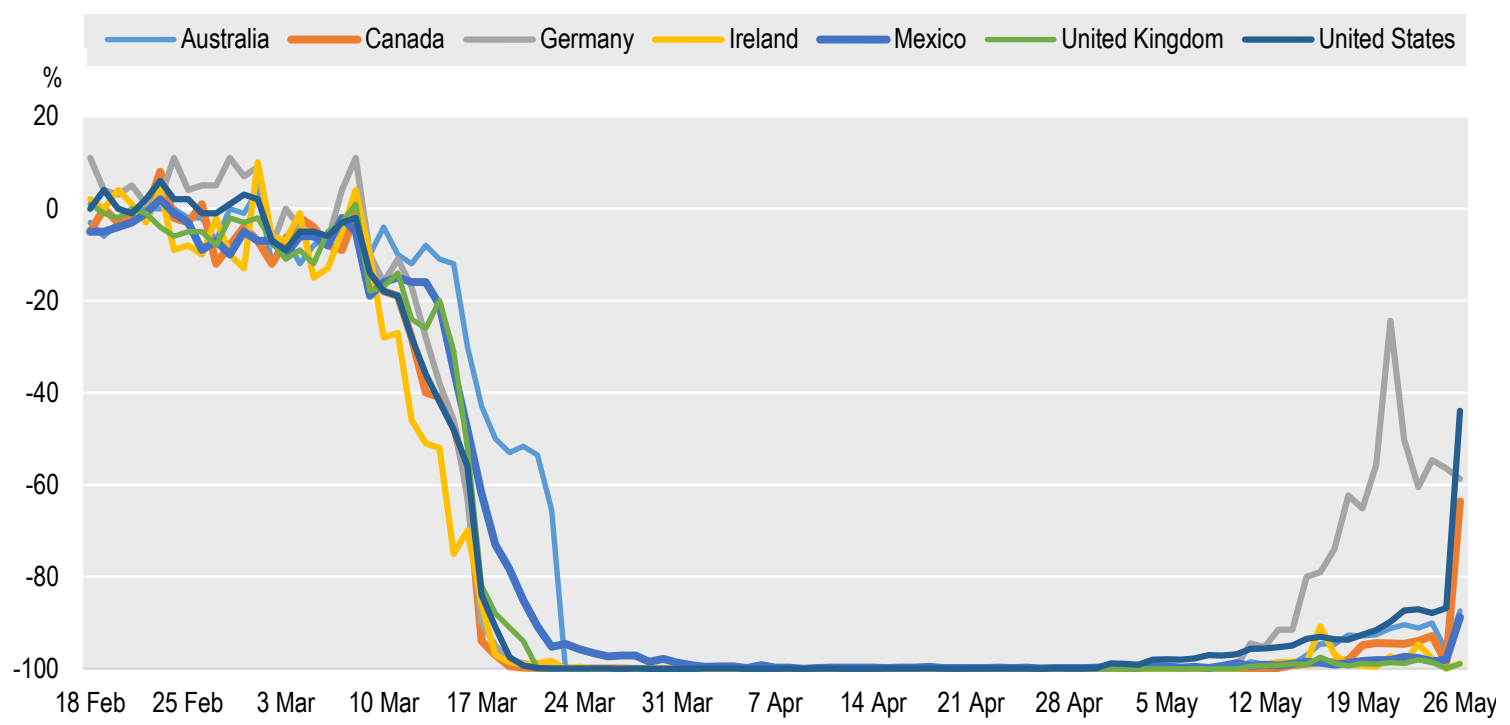

Note: Data includes online reservations, phone reservations, and walk-ins at restaurants on the OpenTable network; estimates are based on a sample of approximately 20000 restaurants.

Source: OpenTable.com.

Figure 2. Retail food demand soared as consumers stockpiled, and has remained high

Demand index for United States in 2020 (same period in $2019=100$ )

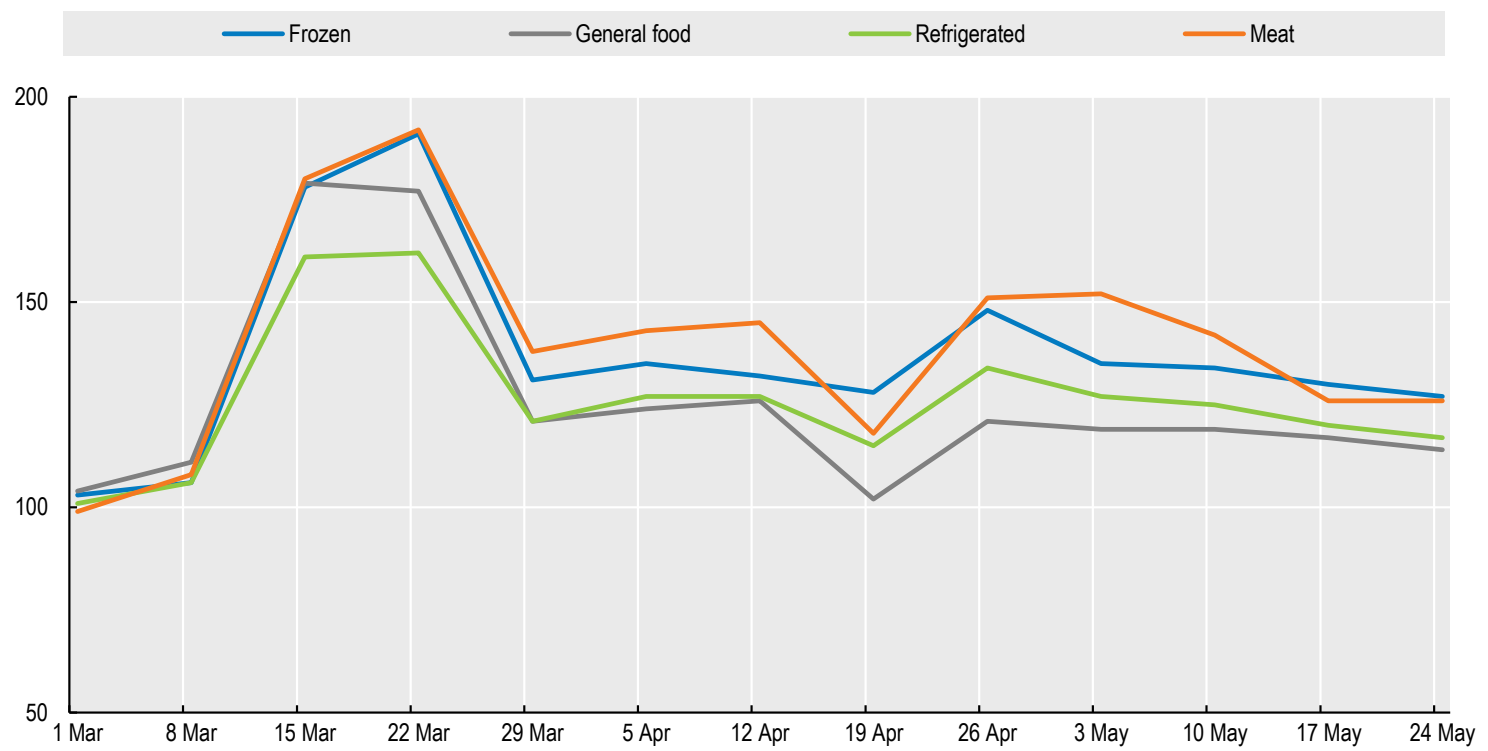

Note: The IRI CPG Demand Index measures weekly changes in consumer purchases (in dollar terms) relative to the same period in the previous year.

Source: IRI, https://advantage.iriworldwide.com/Engineering/covid19/. 


\title{
Yet food supply chains in high-income countries were remarkably resilient
}

While there were clearly stresses and issues, overall, food supply chains in the developed world demonstrated remarkable robustness and resilience in the face of COVID-19. ${ }^{23}$ Responses by policy makers helped, facilitating the functioning of supply chains and avoiding the costly mistakes of the 2007-8 food price crisis.

Grocery store shelves were replenished over time, as consumers reduced the volume of food purchases after initial stockpiling, and as supply chains responded to the exceptional increase in demand. Stocks acted as a first buffer. Despite a general trend towards "just in time" models with limited inventories, various actors along the food supply chain held safety stocks which were drawn down in response to the demand spike. ${ }^{24}$ At the global level, stocks of cereals were also considerably greater than they were on the eve of the 2007-8 food price crisis. ${ }^{25}$

In addition, food processors and retailers took several steps to adapt to COVID-19. ${ }^{26}$ First, they increased operating hours in factories and hired additional employees, with many retailers hiring extra staff. ${ }^{27}$ Second, they reduced the variety of products to focus on the most popular only. This prevented costly and timeconsuming changeovers for manufacturers, and simplified inventory management for retailers. ${ }^{28}$ Third, they found alternative sources of supply when faced with disruptions. For example, when Indian exports of rice became temporarily unavailable, French retailer Carrefour found new suppliers in Pakistan. ${ }^{29}$ Firms which had invested in creating more visibility in their supply chain seem to have fared better. ${ }^{30}$ Similarly,

\begin{abstract}
${ }^{23}$ See, for example, The Economist, "The World's Food System Has So Far Weathered The Challenge of COVID-19 - But things could still go awry", 9 May 2020, https://www.economist.com/briefing/2020/05/09/the-worlds-food-systemhas-so-far-weathered-the-challenge-of-covid-19; and Peter Rubinstein, "Why Grocery Shelves Won't Be Empty for Long," BBC Worklife, 2 April 2020, https://www.bbc.com/worklife/article/20200401-covid-19-why-we-wont-run-out-offood-during-coronavirus. On the distinction between robustness (a limited impact of shocks) and resilience (a quick rebound after a shock) of Global Value Chains in the context of COVID-19, see for example S. Miroudot, "Resilience Versus Robustness in Global Value Chains: Some Policy Implications", in: Richard Baldwin and Simon Evenett (eds.), COVID-19 and Trade Policy: Why Turning Inward Won't Work, VoxEU.org e-book, 29 April 2020, https://voxeu.org/content/covid-19-and-trade-policy-why-turning-inward-won-t-work.
\end{abstract}

24 See Peter Rubinstein, "Why Grocery Shelves Won't be Empty for Long," BBC Worklife, 2 April 2020, https://www.bbc.com/worklife/article/20200401-covid-19-why-we-wont-run-out-of-food-during-coronavirus.

${ }^{25}$ See Schmidhuber, J. and Qiao, B., “Comparing Crises: Great Lockdown versus Great Recession”, FAO Publications, Rome, https://doi.org/10.4060/ca8833en.

26 The mechanisms discussed here were outlined by Peter Rubinstein, “Why Grocery Shelves Won't Be Empty for Long," BBC Worklife, 2 April 2020, https://www.bbc.com/worklife/article/20200401-covid-19-why-we-wont-run-out-offood-during-coronavirus.

${ }^{27}$ See, for example, in the United Kingdom: "Supermarkets Tesco, Asda, Aldi and Lidl go on hiring spree", BBC News, 21 March 2020, https://www.bbc.com/news/business-51976075. For Amazon and Walmart, see Hayley Peterson, "Amazon and Walmart are ramping up hiring to add 250,000 new jobs", 23 March 2020, https://www.businessinsider.fr/us/amazon-walmart-hiring-how-to-apply-2020-3.

${ }^{28}$ See, for example, Simon Jack, “Coronavirus : Supermarkets 'Drastically' Cutting Product Ranges”, BBC News, 19 March 2020, https://www.bbc.com/news/business-51961624; World Economic Forum, "5 Things Supermarkets Want You to Know Right Now", 20 March 2020, https://www.weforum.org/agenda/2020/03/supermarkets-grocerycoronavirus-covid19-supply/.

29 The Economist, "The world's food system has so far weathered the challenge of COVID-19 - But things could still go awry", 9 May 2020, https://www.economist.com/briefing/2020/05/09/the-worlds-food-system-has-so-farweathered-the-challenge-of-covid-19. Indian supplies were disrupted as Indian rice traders stopped signing rice export deals due to logistics bottlenecks; exports resumed in mid-April after a three week pause. See Reuters, "Indian traders signing rice export deals again after 3-week pause", 16 April 2020, https://economictimes.indiatimes.com/markets/commodities/news/indian-traders-signing-rice-export-deals-againafter-3-week-pause/articleshow/75184584.cms?from=mdr.

${ }^{30}$ See, for example, Thomas Y. Choi, Dale Rogers and Bindiya Vakil, "Coronavirus Is a Wake-Up Call for Supply Chain Management," Harvard Business Review, 27 March 2020, https://hbr.org/2020/03/coronavirus-is-a-wake-up-call-forsupply-chain-management; Lisa Goller, "COVID-19 Impact: The State - and Future - of the Supply Chain," 18 May 2020, https://www.rangeme.com/blog/covid19-impact-the-state-and-future-of-the-supply-chain/. 
companies which had experience with other types of disruptions (e.g. hurricanes) seem to have been better prepared. ${ }^{31}$

Supply chain actors also expanded the use of new delivery methods such as "click and collect" services and online sales. Farmers started using digital technologies and platforms to sell their produce directly to consumers. ${ }^{32}$ Restaurants switched to providing take-out and delivery, with some offering grocery-like services (e.g. selling meal kits rather than prepared food). ${ }^{33}$ Initiatives also emerged to link farmers and restaurants directly to food banks. ${ }^{34}$

The logistics sector similarly adapted to the shocks of COVID-19. As passenger airline travel collapsed in February and March 2020, removing a daily cargo capacity of around 80000 tonnes, the use of specialised private aircraft for freight expanded, adding more than 20000 tonnes of daily capacity. Road transport faced different challenges as activity in non-essential sectors was greatly reduced, while other sectors such as food retail faced demand spikes. Yet the industry adapted quickly: within two weeks, capacity had reoriented. ${ }^{35}$ As transport of food and agriculture products in Europe remained robust relative to other goods, the share of trucks delivering these products increased from one-third of the total before lockdown to more than half during lockdown. ${ }^{36}$

The recovery of logistics was facilitated by policy decisions. Long lines at borders shrank quickly in response to measures taken by policy makers, such as the creation of "green lanes" at intra-EU border crossings where the total time spent on border crossing should not exceed 15 minutes. While new restrictions limiting the number of drivers in a vehicle were necessary, EU Member States suspended other restrictions (e.g. bans on driving at night or driving on weekends). ${ }^{37}$ Policy makers also streamlined certification procedures (e.g. by allowing scanned copies or electronic signatures) and relaxed regulations on trade in food (e.g. some labelling requirements). ${ }^{38}$

Government agencies and industry associations also provided information to food supply chain actors to help them cope with COVID-19, including on best practices for safety and hygiene, on exceptional government support, and market conditions. ${ }^{39}$ Other measures included exemptions of food and agriculture from lockdown restrictions, measures to ensure the health of agriculture and food workers, loosening visa restrictions to attract foreign seasonal workers, and administrative flexibility. (These are discussed in detail in the OECD report Agricultural Policy Monitoring and Evaluation 2020.)

However, the most impactful policy response is probably that policy makers have avoided a repeat of the mistakes of the 2007-8 food price crisis, when initial food price increases were greatly exacerbated by export bans imposed by major exporters (they are estimated, for example, to have accounted for almost

${ }^{31}$ See, for example, Dan Solomon and Paula Forbes, "Inside the Story of How H-E-B Planned for the Pandemic", TexasMonthly, 26 March 2020, https://www.texasmonthly.com/food/heb-prepared-coronavirus-pandemic/.

${ }^{32}$ See Natasha Foote, "Innovation spurred by COVID-19 crisis highlights 'potential of small-scale farmers'”, Euractiv, 2 April 2020, https://www.euractiv.com/section/agriculture-food/news/innovation-spurred-by-covid-19-crisishighlights-potential-of-small-scale-farmers/.

${ }^{33}$ See, for example, Holly Petre, "Restaurants pivot to groceries and meal kits to save business during the COVID-19 pandemic", Nation's Restaurant News, 20 March 2020, https://www.nrn.com/delivery-takeout-solutions/restaurantspivot-groceries-and-meal-kits-save-business-during-covid-19.

34 See, for example, Esther Taunton, "Farmers to 'Meat the Need' of food banks", 21 April 2020 , https://www.stuff.co.nz/business/farming/121123117/farmers-to-meat-the-need-of-food-banks.

35 See Sixfold.com, "Effects of Covid-19 on Europe's Road Freight Market”, 12 May 2020,

https://sixfold.com/news/effects-of-covid-19-on-europe-s-road-freight-market.

${ }^{36}$ See Shippeo.com, "COVID-19: The new delivery landscape", 23 April 2020,

https://www.shippeo.com/blog/infographic-covid-19-the-new-delivery-landscape.

${ }^{37}$ See European Commission, "Communication from the Commission on the implementation of the Green Lanes under the Guidelines for border management measures to protect health and ensure the availability of goods and essential services", C(2020) 1897 final, 23 March 2020.

38 See World Trade Organization, "Standards, Regulations and COVID-19: What Actions Taken by WTO Members?", 20 May 2020, https://www.wto.org/english/tratop e/covid19 e/standards report e.pdf.

${ }^{39}$ See https://www.bordbia.ie/industry/covid-19/. 
half of the increase in rice prices). ${ }^{40}$ Although some countries introduced export restrictions during the current crisis, overall their number and impact were limited. ${ }^{41}$ Moreover, WTO members responsible for two-thirds of global exports of agriculture and agri-food products issued a joint declaration expressing their commitment to keep international trade open. ${ }^{42}$

\section{Implications}

The significance of COVID-19 for food supply chains came less from its impact on primary production or overall food demand than from its disruptive effects on the complex web of actors connecting farm to fork, and the sudden change in the demand mix. These disruptions were mostly domestic in nature. Disruptions in processing, in particular for meat, can "disconnect" supply and demand, creating simultaneous surpluses for producers and shortages for consumers, while for some specific products, demand also decreased, leading to a temporary oversupply (e.g. potatoes for French fries, or milk for cheese). ${ }^{43}$ At the same time, shoppers sometimes experienced empty shelves in supermarkets during the early days of COVID-19, as food supply chains adjusted to the sudden demand shifts and surge..$^{44}$

However, the main risk to food security eventually did not come from disruptions along supply chains, but rather from the devastating effects of COVID-19 on jobs and livelihoods. Especially in developing countries, where social safety nets are generally less well-developed, COVID-19 led to a severe increase in poverty and hunger. ${ }^{45}$ The World Food Programme estimated that by November 2020 , the total number of people in acute food security had increased to 270 million worldwide, an increase of $82 \%$ compared to one year earlier. ${ }^{46}$ The vast majority of this increase took place in developing countries, but even within developed countries, more vulnerable groups such as the elderly, chronically ill, and poorer households were at risk, as COVID-19 laid bare pre-existing gaps in social protection systems. ${ }^{47}$ As lockdown measures and other COVID-19-related disruptions led to a global recession, millions lost their livelihoods or experienced a severe drop in their incomes. Social safety nets and food assistance programs were thus essential (and in many cases continue to be) to avoid an increase in hunger and food insecurity.

\footnotetext{
40 See Will Martin and Kym Anderson (2011), "Export Restrictions and Price Insulation during Commodity Price Booms", World Bank Policy Research Working Paper 5645, May 2011.

${ }^{41}$ See, for example, David Laborde, Abdullah Mamun and Marie Parent (2020), "COVID-19 Food Trade Policy Tracker" (dataset), International Food Policy Research Institute (IFPRI), https://www.ifpri.org/project/covid-19-food-trade-policytracker.

${ }^{42}$ World Trade Organization, "Responding to the COVID-19 Pandemic with Open and Predictable Trade in Agricultural and Food Products", 14 May 2020, WT/GC/208/Rev.1; G/AG/30/Rev.1.

${ }^{43}$ See Rabobank, "European Food Supply: Business Is Far From Usual”, April 2020, https://research.rabobank.com/far/en/sectors/regional-food-agri/european-food-supply-business-far-from-usual.html; and Bloomberg Business, "Food Makers Get Shot of Reality Now that Panic Buying Has Waned", 16 April 2020, https://www.bloomberg.com/news/articles/2020-04-16/with-panic-buying-waning-big-food-sees-life-withoutrestaurants.
}

44 Peter Rubinstein, "Why grocery shelves won't be empty for long," BBC Worklife, 2 April 2020, https://www.bbc.com/worklife/article/20200401-covid-19-why-we-wont-run-out-of-food-during-coronavirus. As shown above, weekly demand for some food products in retail stores increased by $50 \%$ or more during the initial phases of the pandemic, but eventually demand settled at levels some $20 \%$ above what would normally be expected.

${ }^{45}$ See, for example, David Laborde, Will Martin and Rob Vos, "Poverty and food insecurity could grow dramatically as COVID-19 spreads", 16 April 2020, IFPRI Blog, https://www.ifpri.org/blog/poverty-and-food-insecurity-could-growdramatically-covid-19-spreads.

${ }^{46}$ See WFP, Global Update November 2020, https://www.wfp.org/publications/wfp-global-update-covid-19-november$\underline{2020}$

${ }^{47}$ See OECD (2020), "Supporting livelihoods during the Covid-19 crisis: Closing the gaps in safety nets", 20 May 2020, http://www.oecd.org/coronavirus/en/. 


\title{
3. COVID-19 and the fisheries and aquaculture sectors
}

\begin{abstract}
Fisheries and aquaculture provide nutritious food for hundreds of millions of people around the world and livelihoods for over $10 \%$ of the world's population. All aspects of fish supply chains were strongly affected by the COVID-19 pandemic, with jobs, incomes and food security all at risk. Government and industry responses addressed the immediate economic and social hardships that the crisis provoked in the fish sector. But governments also need to maintain long-term ambitions for protecting natural resources and ecosystems, and the viability of fisheries. Economic, equity and environmental considerations all point to similar best practices: supporting the incomes of those most in need rather than subsidising inputs or fishing effort, and ensuring that evidence-based management remains in place and is enforced. Transparency in policy responses helps build trust in the future of fish value chains and markets, and enable learning from the crisis to improve the sustainability and resilience of fisheries and aquaculture.
\end{abstract}

\section{Impacts of COVID-19 on the fisheries and aquaculture sectors}

All aspects of fish supply chains were strongly affected by the COVID-19 pandemic, with jobs, incomes and food security all at risk.

\section{Demand for fish products saw important changes}

As with food supply chains more generally, fish products saw important changes in demand. The closure of restaurants and cancellation of events resulted in a collapse in demand for certain fish products, in particular high-end products, such as lobsters, oysters, bluefin tuna, and mahi-mahi. Many fish markets were closed, while trade was further affected by border closures and disruptions to global air freight. These disruptions in turn often led to reduced and more volatile prices. Data from the European Market Observatory for Fisheries and Aquaculture, for example, showed price declines in Mediterranean fisheries in early 2020 of $20 \%-70 \%$, along with high weekly price volatility in other European fisheries.

The reduction in demand for fresh fish products was accompanied by an increase in demand for canned, frozen and processed fish, driven by consumer stockpiling in the early stages of the pandemic. That said, in some places, COVID-19 increased the demand for locally-sourced fish. For example, small-scale fishers from Lake Victoria in Kenya saw prices for their catch rise, as imports of frozen fish from China declined. In several countries, direct delivery services connecting fishers and consumers expanded. These either connect individual fishers to consumers (e.g. Poiscaille in France, Two Hands in Australia and JD Fresh in China) or work through local fisher associations. These services represent only a small share of fish distribution but their development could have lasting impacts on fish supply chains.

\section{Production was disrupted at several stages in the supply chain}

The declining demand and prices for fish discouraged production in many places. Fishers refrained from going to sea, resulting in large declines in production - around $50 \%$ lower for French fisheries in early April 2020 compared to the previous year, and up to $80 \%$ fewer vessels operating in the Mediterranean. Conversely, fishing fleets from Norway and the Russian Federation (hereafter "Russia") appear to have continued largely as normal. Aquaculture producers seem to have been able to maintain production and sales better where they were already selling to supermarkets and were thus already accustomed to meeting the requirements of processed and pre-packed products (this was the case, for example, for seabass and seabream farmers in ltaly).

Difficulties were compounded by public health measures, which reduced production capacity and increased costs all along supply chains. In onshore fish processing facilities, which generally have a large number of workers in a confined space, implementing social distancing while maintaining the same number of workers was logistically challenging, if not impossible. Outbreaks of the virus led to facility shutdowns in 
both Chile and the United States. Firms also incurred additional costs for personal protective equipment. ${ }^{48}$ These issues were even more pronounced on fishing vessels. An outbreak on a fishing vessel can have even more serious consequences, particularly in distant water fleets, where vessels can stay at sea for up to several months and treatment is not immediately available. There were also risks to local communities upon the return to port, as vessels could serve as vectors for the disease to remote communities and could prolong the epidemic.

Limits on the mobility of people and lockdowns also affected production, especially where fisheries were not exempted from lockdown measures. For example, in India, shrimp hatcheries were forced to destroy unsold seed stock. In Peru, the world's largest producer of fishmeal and one of the largest producers of fish oil, processing facilities were effectively shut down due to national lockdown measures. In addition, a number of pre- or post-production processes became more challenging, from port protocols and operations, to processing, as well as trade-related processes such as inspections of goods in relation to sanitary and phyto-sanitary measures, product testing, and certification.

The sector is particularly vulnerable to crises that restrict the movement of goods across borders. For example, the fishery for North Sea Brown Shrimp, which are landed in Germany and then peeled in Morocco, experienced significant logistical difficulties.

\section{Policy responses}

Governments often excluded fish production from lockdown orders. ${ }^{49}$ Support policies in response to the COVID-19 pandemic should be time-limited, targeted, cash-based, and consistent with longer-term sustainability objectives. ${ }^{50}$ Because capture fisheries depend on renewable natural resources, the design and implementation of specific support measures also has direct implications for fishing and the sustainability of resources over the long term. It is important to ensure that support policies do not encourage overfishing; illegal, unregulated and unreported (IUU) fishing; as well as other fishing practices that destroy ocean ecosystems and compromise the sustainability of resources.

Fortunately, economic, equity and environmental considerations all point to similar best practices in terms of support to fisheries. Policies that lower the cost of inputs, such as fuel or vessel construction or modernisation, are among the most likely to create incentives to fish more intensively and promote unsustainable fishing - while at the same time leading to less inclusive outcomes, by favouring large fishers over small producers. ${ }^{51}$ In 2017, such policies accounted for $40 \%$ of the direct support to individuals and companies in the fisheries sector reported by the 27 OECD countries that participate in the OECD Fisheries Support Estimate database. ${ }^{52}$ Thus, the goal should be to move away from such measures and where necessary instead support income directly with targeted cash transfers, to the benefit of the environment and the sustainability of the sector as well as the livelihoods of fishers.

\footnotetext{
${ }^{48}$ FAO (2020), How is COVID-19 Affecting the Fisheries and Aquaculture Food Systems?, Food and Agriculture Organization of the United Nations, Rome, https://doi.org/10.4060/ca8637en.
}

49 OECD (2020), COVID-19 and the Food and Agriculture Sector: Issues and Policy Responses, OECD Publishing, https://read.oecd-ilibrary.org/view/?ref=130 130816-9uut45lj4q\&title=Covid-19-and-the-food-and-agriculture-sectorIssues-and-policy-

responses\&utm source=Adestra\&utm medium=email\&utm content=Read\%20the\%20brief\&utm campaign=Agricult ure\%20COVID\%20blast\&utm t .

50 OECD (2020), Government Support and the COVID-19 Pandemic, OECD Publishing, https://read.oecdilibrary.org/view/?ref=128 128572-w5qyf5699d\&title=Government-support-and-the-COVID-19-pandemic.

51 Martini, R. and J. Innes (2018), "Relative Effects of Fisheries Support Policies", OECD Food, Agriculture and Fisheries Papers, No. 115, OECD Publishing, Paris, https://dx.doi.org/10.1787/bd9b0dc3-en.

52 The OECD Fisheries Support Estimate (FSE) database measures fisheries support policies in a consistent and transparent way across all OECD countries and other important fishing economies. The FSE and associated modelling work allow investigation of the impacts of fisheries support policies on resources and ecosystems, as well as on jobs, incomes and value creation, with a view to guiding policy makers in adjusting policies to better deliver on their stated goals. 
Direct support can be partially decoupled from fishing activities, for example via income support and special insurance systems. Such approaches proved popular with governments: in addition to general stimulus packages, fisheries-specific income support measures were implemented in the United Kingdom, the United States, Canada and Japan among others. ${ }^{53}$ In many countries, economic stimulus packages including grants, interest free loans, wage guarantees and macro fiscal policies, are being used to protect jobs and incomes across the entire economy - including fisheries and aquaculture. In many cases, however, fisheries operators favour business structures that are rare in other sectors, such as revenue sharing among crew on individual vessels, which can be excluded from compensation systems for technical reasons. In addition, work seasonality, the employment of foreign crew and seasonal workers on vessels, and relatively high levels of informality and self-employment, mean that general stimulus packages may not be as effective for fisheries and aquaculture. Whether or not fisheries-specific support programmes are required, as well as their extent, will depend on both the national context of the sector and how it interacts with the complex and hard-to-predict impacts of the COVID-19 pandemic.

Benefits can also be given in exchange for permanent or temporary capacity reduction, such as through decommissioning schemes or payments for early retirement. The crisis prompted temporary changes to the European Marine Fisheries Fund (EMFF) allowing EU Member states to pay fishers and aquaculture producers for a reduction or cessation in production. Ireland, for example, offered a voluntary scheme designed to support fixed costs incurred by vessel owners while their fleets are tied up, which operated from June to August 2020. ${ }^{54}$ Such efforts can help to stabilise prices and reduce oversupply in depressed markets. These measures are also sometimes used with a view to protect quota availability for later. Whether they lead to longer term reductions in fishing pressure, and ultimately to healthier fish stocks, therefore depends on whether they are implemented in ways that do not allow fleet re-capitalisation, or whether they in effect simply postpone fishing effort.

Governments can also finance services that benefit the fisheries sector as a whole. Services that target fishers' ability to operate their businesses by promoting market diversification may prove helpful in the COVID context, especially for countries where fish production is largely export-oriented. Initiatives to support the development of new markets and the promotion of seafood consumption domestically have been implemented by governments in Australia, Japan, the United Kingdom, Chile, China, Peru, Thailand, and Indonesia.

These efforts have been complemented, in several places, by support for airfreight to maintain important international routes for high-value products, such as rock lobsters in Australia and New Zealand, which have suffered disproportionately from the collapse of air travel. The fish sector also benefited from wider measures taken to facilitate trade-related processes and border formalities such as acceptance of digital versions of required certificates, or 24/7 clearance for food goods in major ports. ${ }^{55}$

Governments also increased support to help fisheries make up for lost demand. Campaigns to encourage the consumption of local fish were organised in many countries; in Costa Rica, for example, they were complemented by support for direct sales programmes. ${ }^{56}$ Funds were also allocated to market diversion initiatives such as purchasing, transporting and storing of species that are experiencing large declines in demand and prices due to COVID-19; in Japan, for example, about USD 30 million was set aside for such measures. Removing production from the market temporarily, including through cold storage, was 53 Within the European Union (EU), these programmes took advantage of changes to EU regulations on state aid,
which doubled the ceiling for individual instances to EUR 120000 (USD 130360 ), and provided additional flexibility
on the use of funds from the European Marine Fisheries Fund (EMFF). In Korea, the government set aside KRW 3
billion (USD 2.4 million) to provide low interest (1.3\%) loans to aquaculture households and fisheries businesses facing
cash flow difficulties due to COVID-19. Fee waivers and deferrals were also used to reduce costs to fishers. For
example, in Australia all fees in Commonwealth fisheries for 2020 have been waived; likewise, in Canada, the Nova
Scotia Fisheries and Aquaculture Loan Board deferred all fees until the end of June 2020 .

${ }^{54}$ https://mailchi.mp/eumofa/eumofa-monthly-highlights-1041997?e=7bc227799a.

55 OECD (2020), Trade Facilitation and the COVID-19 Pandemic, OECD Publishing, https://read.oecdilibrary.org/view/?ref=130 130609-v8jn83j1j3\&title=Trade-facilitation-and-the-covid-19-pandemic.

${ }^{56}$ https://www.guanacastealaaltura.com/index.php/la-provincia/item/3839-procuran-alivio-a-pescadores-anteemergencia-por-covid-19-con-iniciativas-de-comercializacion-directa. 
important for aquaculture products where demand decreased but production cannot be easily slowed or stopped. Such efforts also help reduce loss and waste of fish products across the supply chain.

Many of the programmes adopted were time limited. For example, in the United Kingdom, the GBP 9 million (USD 11.1 million) grant-making fund for fisheries was limited to three months, and the changes to the EMFF expired at the end of 2020. It is crucial that support programmes do not become permanent, which could result in increased fishing pressure and unfair competition. To target support to those who need it most, it is also crucial that governments continue to invest in monitoring the economic and social impacts on fisheries and aquaculture production systems, associated supply chains, and fish consumption patterns.

Finally, support policies generally lead to more benefits for fishers and are less likely to encourage unsustainable fishing when an effective management system is in place (in particular with limits on total allowable catch) ${ }^{57}$ Understanding the impacts of the pandemic on fisheries management systems is crucial and countries will need to continue to invest in science-based stock management and measures to counter IUU fishing.

\section{Fisheries management policies must remain evidence-based}

Making wise use of public resources is only part of the story. Sustainability - environmental, economic and social - also depends on maintaining and enforcing an appropriate regulatory framework. This may be challenging given the COVID-19 crisis. Policy makers face pressure to make up for income losses in the sector. While loss of income is generally better compensated directly, governments are looking for lowcost options to lessen hardship. Relaxing constraints on fishing, rather than having to disburse cash, may be seen as one such option. Management changes have already been implemented in a number of countries, including extension of fishing areas and seasons as well as quota deferrals. But such changes could increase the pressure on stocks, with potentially lasting consequences. Given the complexity of the relationship between fishing effort and the health of fish stocks, and increased pressures on fisheries from climate change, countries should adopt a cautious and evidence-based approach to management changes.

Such an approach will be even more important as monitoring and enforcement are also impeded by the need for social distancing, which have led, for example, to the waiving of requirements for fisheries observers ${ }^{58}$ in several regions. ${ }^{59}$ Observer requirements were notably waived in both domestic fisheries (e.g. for 45 days in Canada), and international fisheries (e.g. by the Western and Central Pacific Fisheries Commission until 31 July). The absence of observers presents an opportunity for unscrupulous operators to engage in IUU fishing. Declining government revenues from sector-specific taxes through fee deferrals could also reduce budgets for management control and monitoring.

Countries can try to offset these impacts by strengthening and supporting remote monitoring efforts and accelerating the uptake of technological solutions, which reduce the need for in-person observation. Mandatory use of vessel monitoring systems (VMSs) ${ }^{60}$ or automatic identification systems (AIS), ${ }^{61}$ which monitor where vessels are fishing, can ease enforcement. Catch documentation schemes and verification

\footnotetext{
${ }^{57}$ Martini and Innes (2018), Ibid.

58 Fishing observers are independent specialists employed by government agencies to monitor vessel activities.

${ }^{59}$ Border closures have further exacerbated these issues as repatriating observers after trips has become difficult.

60 VMS are used in commercial fisheries to allow regulators to track the activities of fishing vessels. The functionality of the system and the associated equipment varies with the requirements imposed by regulations pertaining to fishing in the area in which the vessel is operating. The systems are administered regionally or nationally, and access to the data is restricted. However, some countries are starting to opt for transparency on their VMS data.

61 Adopted in 2000 by the IMO, the automatic identification system (AIS) was initially developed for navigational safety goals and to prevent ship collisions. Vessels carrying AIS transponders broadcast information about their identity, position and course. The stream of real-time data generated on vessel positions provides a good understanding of routine vessel operations, which can also help inform costal surveillance and traffic management. Using algorithms developed by machine learning, AIS-derived data can be assessed for potential irregularities, helping to detect IUU activities (especially as AIS data are not bound by confidentiality and can be purchased from data vendors).
} 
of catch logbooks, which note the details of the fishing activity undertaken, can also help enforce regulations on the size and composition of harvests at landing. Such requirements were universal for commercial operations in OECD countries reviewed in 2016, as well as for vessels operating under the management of Regional Fisheries Management Organisations. ${ }^{62}$ Enlarging such requirements wherever possible, including through development co-operation, should be a priority for maintaining monitoring, control and surveillance throughout the crisis and avoiding surges in IUU fishing globally.

Maintaining appropriate management, control and surveillance may be even more challenging for fisheries managed by Regional Fisheries Management Organisations (RFMOs). The cancellation and delay of RFMO meetings could hamper international co-operation and reduce transparency, especially if they lead to delays in adoption of necessary measures and in independent performance of reviews of parties. Countries should collectively work on ways to minimise the impacts of COVID-19 on the operation of RMFOs and the management of international fisheries.

\title{
Transparency and co-operation remain fundamental to good fisheries management
}

Transparency of policy responses is critical to build the trust that governments need at home and abroad to boost confidence in trade and global markets, to manage business expectations, and to maintain political support regarding the use of public funds. ${ }^{63}$

Transparent information on policy responses to the crisis is also crucial to enable countries to learn from each other's experiences. Reaching an international agreement on the phasing-out of harmful fisheries support policies at the WTO remains essential. But countries can also make progress independently and implement their proposed cuts in harmful support without waiting for a deal to be concluded.

To contribute to the need for transparent information, the OECD has been keeping track of support measures and changes to fisheries management adopted in the context of the COVID-19 crisis. On the basis of this information and monitoring, the OECD is working with other organisations to support governments through timely and objective evidence and analysis to inform policy choices.

The importance of transparency is not limited to fisheries management, however. As the next section shows, transparency was also essential in avoiding a COVID-19 induced food crisis.

\section{The role of transparency in avoiding a COVID-19 induced food crisis}

\begin{abstract}
Early in the COVID-19 outbreak, there were concerns that a large-scale food crisis would develop, similar to the 2007-08 food price crisis, when panic buying and counterproductive policies exacerbated initial supply disruptions. This was avoided in part thanks to improved transparency in global staple crop markets. Transparency on market conditions and policies is critical in helping reduce market uncertainty, exposing bottlenecks and highlighting risks, all of which help market participants and policy makers develop more effective responses in times of crisis. Yet, transparency is not automatic: it requires investments in gathering comparable information, monitoring market and policy developments, and communicating clearly about the findings. This section discusses transparency, using the example of the Agriculture Market Information System (AMIS), a G20 initiative created in response to the 2007-08 food price crisis. While AMIS focuses on major staple crops (wheat, maize, rice and soybeans), experience with AMIS can provide insights for the wider agriculture and food sector.
\end{abstract}

\footnotetext{
${ }^{62}$ Hutniczak, B., C. Delpeuch and A. Leroy (2019), "Closing Gaps in National Regulations Against IUU Fishing", OECD Food, Agriculture and Fisheries Papers, No. 120, OECD Publishing, Paris, https://dx.doi.org/10.1787/9b86ba08-en and Hutniczak, B., C. Delpeuch and A. Leroy (2019), "Intensifying the Fight Against IUU Fishing at the Regional Level", OECD Food, Agriculture and Fisheries Papers, No. 121, OECD Publishing, Paris, https://dx.doi.org/10.1787/b7b9f17den and

${ }^{63}$ OECD (2020), COVID-19 and International Trade: Issues and Actions, OECD Publishing, https://read.oecdilibrary.org/view/?ref=128 128542-3ijg8kfswh\&title=COVID-19-and-international-trade-issues-and-actions.
} 


\section{Introduction}

Timely responses by both public and private actors have played an important role in ensuring the continued functioning of food supply chains during the COVID-19 pandemic. Effective responses require access to reliable information about market conditions (such as production and stock levels, demand, and trade flows), and policy measures around the world. This transparency helps to reduce market uncertainty, expose bottlenecks and highlight risks. This in turn helps to avoid panic buying and counterproductive policy interventions. Yet, achieving this transparency requires ongoing investments in gathering comparable information, monitoring developments, and communicating market conditions clearly. That is, the availability of reliable information in times of crisis depends in large part on investments made during calmer times.

This section discusses the importance of transparency and the different requirements for effective information-sharing, using the example of the Agricultural Market Information System (AMIS). The OECD, together with the World Trade Organisation (WTO), leads the work on policy monitoring, reporting and analysis for the AMIS initiative. While this initiative focuses on the world's major staple crops (wheat, maize, rice and soybeans), experience with AMIS can provide insights for the wider agriculture and food sector.

\section{Box 2. The Agricultural Market Information System (AMIS)}

The Agricultural Market Information System (AMIS) is an inter-agency platform that aims to avoid or defuse food price crises by enhancing the transparency of food markets and ensuring effective policy responses. To achieve this, AMIS provides timely information on the global supplies of staple crops (wheat, maize, rice and soybeans) and improves policy coordination in international food markets.

Launched in 2011 by the G20 Ministers of Agriculture against the background of the food price spikes of 2007/08 and 2010, AMIS is composed of 28 countries: the G20 members plus Spain, and seven additional major exporting and importing countries of AMIS crops (Egypt, Kazakhstan, Nigeria, the Philippines, Thailand, Ukraine, and Viet Nam). Together, AMIS participants represent around $80-90 \%$ of global production, consumption and trade volumes of the targeted crops.

The AMIS Secretariat consists of ten international organisations, including the OECD, which each bring their comparative advantage and expertise to the initiative.

For more information: www.amis-outlook.org.

Note: These ten international organisations are: the Food and Agriculture Organization of the United Nations (FAO), Group on Earth Observations Global Agricultural Monitoring (GEOGLAM), International Food Policy Research Institute (IFPRI), International Fund for Agricultural Development (IFAD), International Grains Council (IGC), Organisation for Economic Co-operation and Development (OECD), United Nations Conference on Trade and Development (UNCTAD), the World Bank Group, World Food Programme (WFP), and World Trade Organization (WTO).

\section{Why transparency matters}

\section{Transparency reduces market uncertainty}

In agricultural and food markets, information on both market conditions and policy developments is crucial to obtain a complete overview of the market situation. Market information on supply and demand balances, prices, and trade and stock volumes needs to be complemented by information on agricultural domestic and trade policies to form a complete picture of the current situation and to anticipate how markets might evolve in the short and medium term.

Consistently publishing this type of information increases transparency and reduces market uncertainty, thereby lowering the risk of people and governments taking damaging decisions based on incomplete information. Conversely, poor access to information can lead to counterproductive decisions with detrimental impacts on people and markets. A striking example related to staple crops is the surge in rice 
prices during the 2007-08 food price crisis. At that time, even though rice supplies were abundant, people, firms and governments started to stock up on rice because they had witnessed soaring wheat and maize prices in the face of shortages due to poor harvests and assumed there would be rice shortages as well. As a result, rice prices started to increase. In response, several large rice exporting countries then implemented export restrictions, thereby effectively reducing supply in the global market and causing the international price of rice to rise significantly, affecting the food security of millions of people around the world for whom rice is a key staple. Had timely, trusted information on the extent of rice stocks and production been available and widely communicated, panic, hoarding and export restrictions and the highly damaging price spikes they caused all could have been avoided.

In the initial period following the global spread of the COVID-19 outbreak, there were multiple reports of panic-buying and hoarding behaviour by consumers, particularly in the first few weeks when lockdowns were announced and implemented. Staple foods, such as wheat-based pasta or rice, were popularly hoarded products because of their long shelf life and because people were anticipating shortages. To halt panic buying and prevent the creation of artificial shortages, some countries started publishing regular reports on supply and demand balances, ${ }^{64}$ and several countries with public stocks of grains announced the levels of grains stored to reassure their citizens that there was sufficient availability to meet domestic demand. Some of those countries (e.g. India, Indonesia, Nigeria, Russia, and Ukraine) also began to distribute food staples from their public stocks to prevent panic buying that could lead to artificial shortages and price increases (Table 2).

\section{Table 1. Public stock distribution by AMIS countries in response to the COVID-19 outbreak}

\begin{tabular}{|c|c|c|}
\hline Country & Commodity & Description \\
\hline India & Food grains & $\begin{array}{l}\text { On } 18 \text { March 2020, the Government of India decided to distribute the six month quota of subsidised food } \\
\text { grains in one go to the beneficiaries of the National Food Security Act in order to counter COVID-19-induced } \\
\text { panic buying and prevent a price increase. }\end{array}$ \\
\hline India & Food grains & $\begin{array}{l}\text { On } 25 \text { March 2020, the Government of India increased the amount of subsidised food grains to the } \\
\text { beneficiaries of the Public Distribution System from } 5 \text { to } 7 \mathrm{~kg} \text { per month to ensure a sufficient supply of food } \\
\text { grains during the lockdown caused by the COVID-19 outbreak. }\end{array}$ \\
\hline India & $\begin{array}{l}\text { Food grains } \\
\text { and pulses }\end{array}$ & $\begin{array}{l}\text { On } 26 \text { March 2020, India's Finance Minister allocated INR } 1.7 \text { lakh crore (around USD } 22 \text { billion) to the PM's } \\
\text { Gareeb Kalyan Scheme. The Scheme included both cash transfers and food distribution. Under the scheme, } \\
800 \text { million poor people received } 5 \mathrm{~kg} \text { wheat or rice and } 1 \mathrm{~kg} \text { of pulses for free every month from } 1 \text { April until } \\
30 \text { June. On } 30 \text { June, India extended the free rations regime until the end of November. }\end{array}$ \\
\hline Ukraine & Wheat flour & $\begin{array}{l}\text { On } 27 \text { March 2020, the Ukrainian Economy Ministry announced that the state-run grain firm DPZKU and } \\
\text { Agrarian Fund would sell } 128000 \text { tonnes of wheat flour on the local market, aiming to curb a jump in prices } \\
\text { caused by fears over the rapid spread of COVID-19. }\end{array}$ \\
\hline Russia & Grains & $\begin{array}{l}\text { At the end of March 2020, Russia announced that it would sell } 1 \text { million tonnes of grain from its state stockpile } \\
\text { of } 1.8 \text { million tonnes on the domestic market to ensure adequate supplies and keep prices down amid the } \\
\text { coronavirus pandemic. }\end{array}$ \\
\hline Nigeria & Grains & $\begin{array}{l}\text { On } 1 \text { April 2020, the President of Nigeria announced the release of } 70000 \text { tonnes of grains from its national } \\
\text { strategic reserves in the coming days in order to counter the potential for food shortages arising from the } \\
\text { spread of COVID-19. }\end{array}$ \\
\hline China & Soybean & $\begin{array}{l}\text { On } 7 \text { April 2020, China, for the second time this year, asked its state-owned stockpiler Sinograin to release to } \\
\text { the state-owned crusher Cofco } 0.5 \text { million tonnes of its own soybean reserve to offset the effect of low stocks } \\
\text { due to shipment delays from Brazil and logistic disruptions amid the COVID-19 pandemic. }\end{array}$ \\
\hline Indonesia & Rice & $\begin{array}{l}\text { Indonesia's state food company Bulog has doubled the volume of rice stocks released for public distribution } \\
\text { as part of its efforts to stabilize prices amid the COVID-19 outbreak. As of } 17 \text { May } 2020 \text {, Bulog had distributed } \\
596305 \text { tonnes of rice from stocks, compared to around } 225685 \text { tonnes during the same period last year. }\end{array}$ \\
\hline China & Maize & $\begin{array}{l}\text { On } 28 \text { May 2020, China started auctioning maize (up to } 4 \text { million tonnes) from its state reserves to address } \\
\text { tightening corn supplies. }\end{array}$ \\
\hline
\end{tabular}

Source: Agricultural Market Information System (AMIS).

${ }^{64}$ Japan's Ministry of Agriculture, Forestry and Fisheries, for example, published online daily updates of the supply and demand for major products (rice, noodles, pasta, milk, fishery products and others) in order to avoid panic buying (https://www.maff.go.jp/j/saigai/n coronavirus/index.html\#c00, in Japanese). 
At the international level, AMIS has been regularly publishing information on market and policy developments for the four major staple crops. Furthermore, all the international organisations that make up the AMIS Secretariat, along with member countries, have been communicating consistent messages on the state of global markets for staples in the context of COVID-19. A key message has been that the global situation for staple crops is very different now compared to the food price crisis of 2007-08. Whereas the situation in 2007-08 was characterised by poor harvests in several key producers, low cereal stocks, a rising oil price, export restrictions, and the depreciation of the US Dollar, the current situation for AMIS crops is much more favourable. Ample global cereal stocks, low energy prices, and good production prospects mean that prices were much lower during the early phases of the COVID-19 crisis than during the food price crisis (Figure 3) with stocks and production levels well above what they were in 2007-08 (Figure 4) and even close to or at record levels for wheat, maize and rice. (Food prices started to increase in the Summer of 2020 and continued to rise in early 2021 as a global economic recovery spurred demand, notably in China. By May 2021, the FAO Food Price Index was more than $30 \%$ higher than the year before. As of June 2021, AMIS analysis suggests these price increases are due to fundamentals and are likely to persist through 2021). ${ }^{65}$

Figure 3. Maize, rice, soybeans and wheat price indices (daily)

3 January 2005 to 16 September 2020 (Jan $2000=100)$

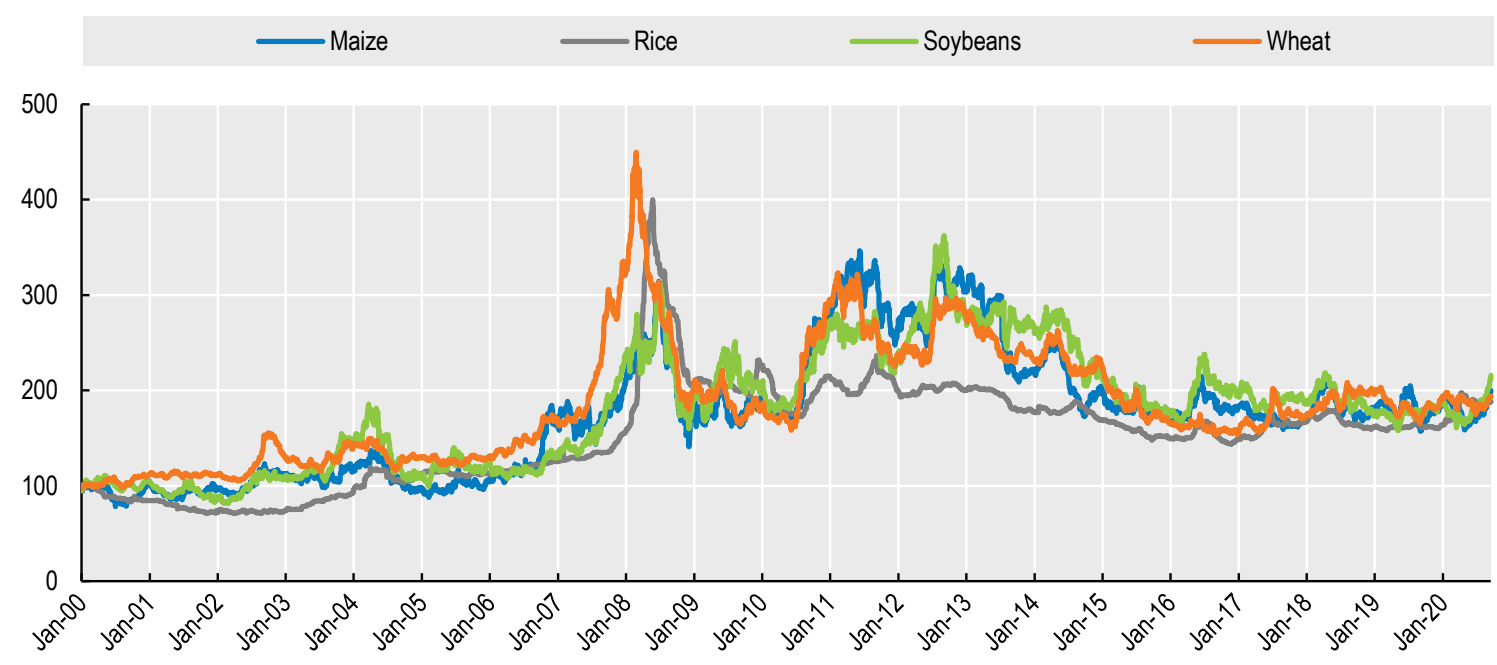

Source: International Grains Council (IGC).

\footnotetext{
${ }^{65}$ See AMIS (2021), "What's behind the recent surge in food prices ? », 7 June 2021, http://www.amisoutlook.org/news/detail/en/c/1154892/.
} 
Figure 4. Production, stocks and utilisation of maize, rice, soybeans and wheat

$2005-2019 / 20$

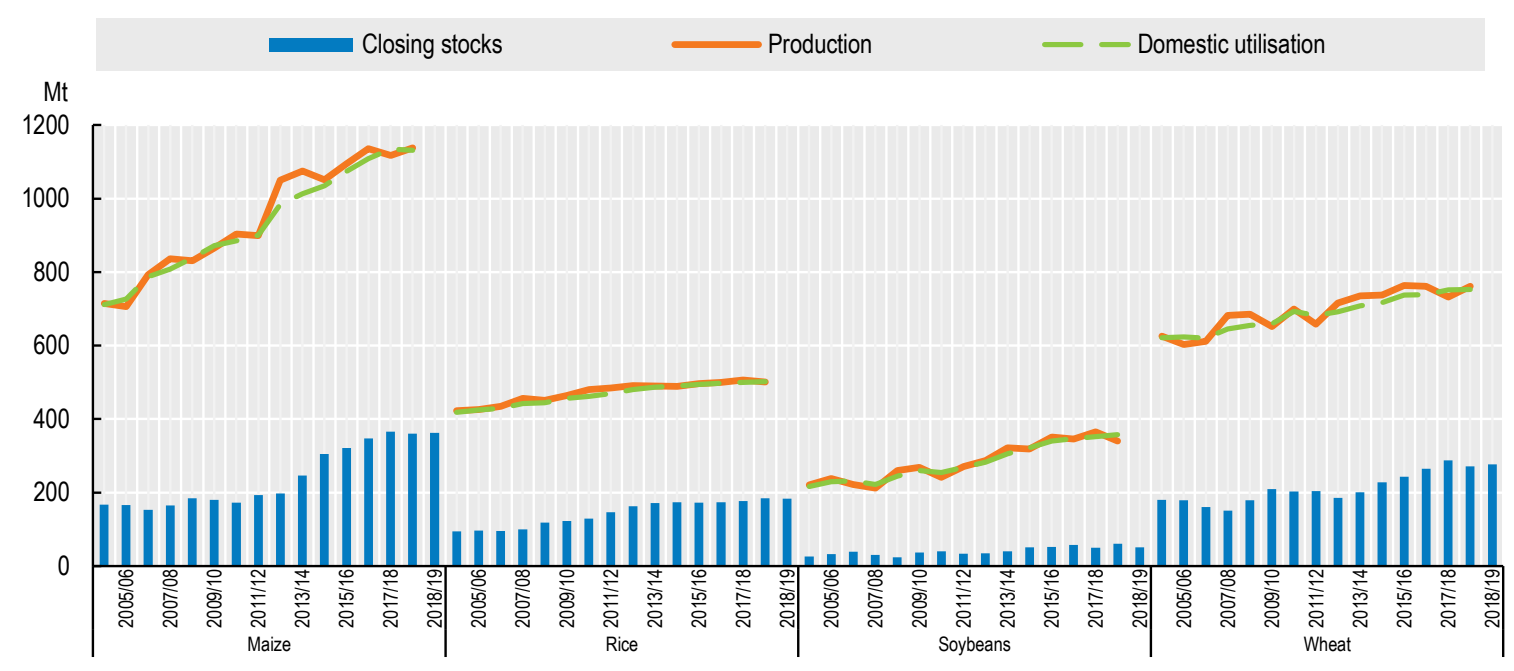

Source: Agricultural Market Information System (AMIS).

\section{Transparency exposes bottlenecks and highlights risks}

The COVID-19 outbreak hit the agriculture and food sector on all fronts: production, consumption, supply chains, and trade. Policy makers required rapid access to accurate and timely information in order to triage problems and ensure that efforts and policies are directed to priority areas.

Understanding how market conditions have changed over time helps policy makers have a perspective in which to assess risks and identify bottlenecks. During crises, it is crucial to establish the extent to which the market situation is deviating from pre-existing trends and how the emerging situation compares to that in the lead-up to, or during, previous crises. This can only be achieved if market indicators and policy decisions have been consistently monitored and the information consistently reported. Obtaining a full picture of the situation also requires the ability to compare information across commodities and combine different types of information (e.g. market and policy information).

In the case of staple crops in the face of COVID-19, investments in transparency meant that information was readily available that quickly revealed that the problem in the market was not related to supply (given the abundance of stocks and favourable production outlooks) but was rather due to sudden demand surges driven by concerns about COVID-19, and to disruptions in trade and transport. Moreover, it showed that, in comparison to other commodities, staple crops were relatively less affected by transportation disruptions; this is because staples are often shipped in bulk, which requires less human interaction in ports, at border posts and on vessels. That said, these commodities were still affected by border procedures and quarantine measures that seriously affected trade, both domestically and internationally. ${ }^{66}$

Comparison of the global situation for different staple crops also revealed that, while global wheat, maize and soybean markets were stable, the rice market needed to be monitored more closely. In early March 2020, international prices for rice started to increase following surges in demand. In April, the FAO's all

66 OECD (2020a), COVID-19 and the food and agriculture sector: Issues and policy responses, OECD Policy Responses to Coronavirus (COVID-19), accessible at http://www.oecd.org/coronavirus/policy-responses/COVID-19and-the-food-and-agriculture-sector-issues-and-policy-responses-a23f764b/. 
rice price index reached its highest level since December 2011, although well below 2007-08 levels. ${ }^{67}$ One of the main contributing factors was the suspension of new export contracts in Viet Nam, the world's third largest rice exporter, as well as in Myanmar, combined with an export ban on rice by Cambodia. Additionally, the national lockdown in India, the world's largest rice exporter, and quarantine measures in Pakistan had resulted in logistical constraints, which also increased uncertainty and pushed prices upwards. However, most export restrictions were removed by May 2020. Transparency about domestic and global market conditions, combined with transparency in policy decisions, prevented the situation from escalating and leading to wider adoption of export restrictions by other countries.

Export restrictions are rarely effective and multiple studies have shown the detrimental effects of these policies on domestic and international markets. ${ }^{68}$ Experience with the impact of export restrictions imposed during the 2007/08 crisis shows that by diverting supplies from world markets, such measures increased food prices and volatility, thereby harming all countries, but in particular countries dependent on food imports. ${ }^{69}$

A number of countries implemented export bans and quotas on staple crops in response to the COVID-19 outbreak (Figure 5). However, information on the prevalence and duration of these policy measures needs to be combined with market information in order for their true impact on world markets to be understood. For example, Russia, the world's largest wheat exporter, introduced a grain export quota for the period April-June, 2020. However, by 26 April, the quota had been filled, which implicitly meant that all grain exports from Russia were de facto suspended until 1 July. Likewise, India is not represented in Figure 5 because it had not explicitly banned exports; instead, exports had been halted because its lockdown severely curtailed shipments. By contrast, Ukraine introduced a wheat export quota in April-June, 2020 to avoid a rise in domestic bread prices, but the actual amount of wheat exports from Ukraine remained at levels similar to those of the previous year.

Obviously, a small exporting country introducing an export restriction will not, by itself, influence international markets. However, the risk is that when one country introduces a restriction, other countries follow suit and the accumulation of export restrictions does indeed affect international markets. It is therefore important to continue monitoring all export restrictions being imposed by any country as they can quickly destabilize markets. Even if such restrictions are only implemented for a short time, their impacts can be significant and affect markets for a long period. ${ }^{70}$

${ }^{67}$ FAO (2020), FAO rice price update May 2020, accessible at http://www.fao.org/economic/est/publications/ricepublications/the-fao-rice-price-update/en/.

68 Anderson Kym, Maros Ivanic, and Will Martin (2013), "Food price spikes, price insulation, and poverty", Policy Research Working Paper, World Bank Development Research Group, Agriculture and Rural Development Group, July.

69 During the COVID-19 outbreak, export restrictions were not limited to the agriculture sector, but were also imposed on other goods such as medical supplies and facemasks (OECD, 2020, The face mask global value chain in the COVID-19 outbreak: Evidence and policy lessons, OECD Policy Responses to Coronavirus (COVID-19), accessible at http://www.oecd.org/coronavirus/policy-responses/the-face-mask-global-value-chain-in-the-COVID-19-outbreakevidence-and-policy-lessons-a4df866d//).

70 Deuss, A. (2017), "Impact of Agricultural Export Restrictions on Prices in Importing Countries", OECD Food, Agriculture and Fisheries Papers, No. 105, http://dx.doi.org/10.1787/1eeeb292-en. 
Figure 5. Export restrictions imposed on staple crops in response to the Covid-19 outbreak

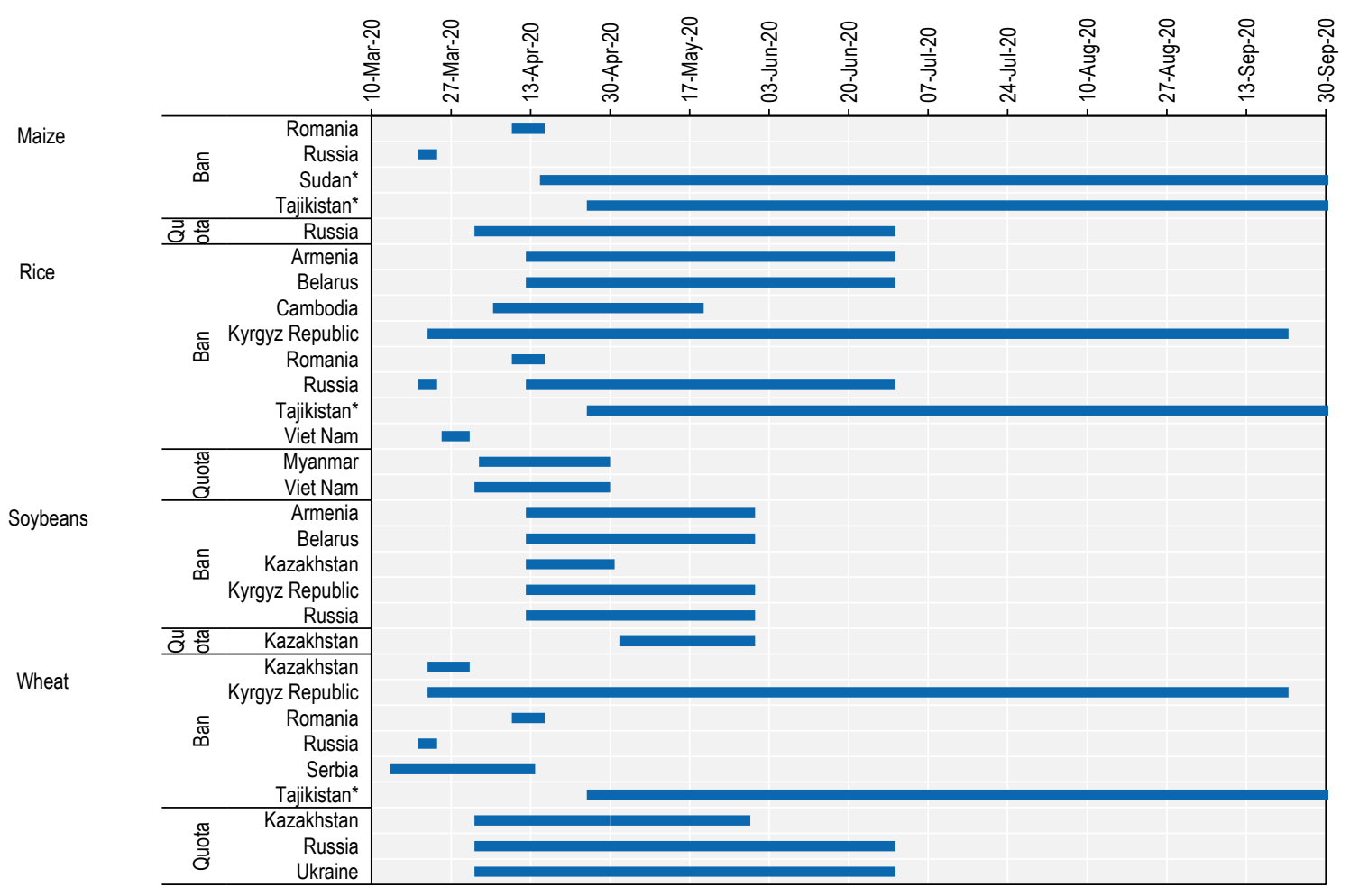

Note: *Indicates measures with no known end date.

Source: OECD compilation.

Even though some countries introduced export restrictions on staple crops in response to the COVID-19 outbreak, transparency about global market conditions prevented a situation where even more countries introduced these measures. Furthermore, transparency about policy measures gave trading partners a better understanding of potential bottlenecks in the supply chain and, by combining this policy information with market information, they were able to adjust accordingly. Increased transparency has also exerted pressure on countries to limit their use of policies that can have detrimental impacts not only domestically, but also on global markets. As a result, relatively fewer export restrictions were introduced than expected and most of these measures were short-lived.

\section{How to improve transparency}

\section{Clarity and comparability are essential}

For policy makers and market participants to be able to fully take advantage of information, it should be presented in a way that is clear and easy to understand. For certain types of information, tables or graphs can be sufficient, but for more complex information, additional explanations may be required. Policy information is, by definition, more qualitative and therefore usually falls under the latter category.

Information on the agricultural and food sector is often collected or published by different institutions, which can make it challenging to compare data across sources within a country, as well as across countries. The AMIS initiative introduced several ways to deal with this issue. First, the different AMIS member countries collaborate with the Secretariat to harmonise market information (e.g. explaining assumptions behind the forecasts, use of the marketing year). Second, AMIS publishes global figures on the market situation by 
different sources ${ }^{71}$ side-by-side to offer users a credible range for the estimates. Third, consistent communication about the data is key. Several meetings and webinars have been organised by the AMIS members where market and policy information could be shared, discussed and validated. This not only helped to ensure trust in the information, but also to ensure the consistent communication from AMIS members that is important for reducing market uncertainty.

\section{Increasing the frequency of monitoring and reporting supports informed decision-making}

Access to frequently updated information is crucial for people to make well-informed decisions. Making investment, planting, trade or policy decisions based on outdated information can have ripple effects that last for a long time. During extreme situations such as the COVID-19 outbreak, economies and market conditions change quickly, underscoring the need to have timely access to up-to-date information to inform decision-making. As soon as market conditions change or new policies are implemented, information needs to be made available so that stakeholders and governments can respond accordingly. Digital technologies have facilitated and simplified the rapid dissemination of information through online reports and video conferences (webinars) among multiple stakeholders. Yet information first must be collected, examined and verified before it can be published, and this can take time.

In agricultural markets, well-established structures are already in place for certain types of information gathering (e.g. price developments), which enables the frequency of reporting to be intensified as needed. However, not all information gathering can be accelerated. For instance, on-field monitoring requires people to inspect crops, which has been complicated during COVID-19 due to movement restrictions. ${ }^{72}$ In addition, certain types of information were not collected prior to the COVID-19 outbreak simply because this type of event had not occurred before (e.g. impacts of lockdown-induced restrictions on movements in the sector). Governments and international organisations needed time to establish the trusted, standardised systems to collect and publish this information.

At the international level, AMIS publishes monthly market and policy information on staple crops in its Market Monitor, but some of the AMIS organisations (e.g. the International Grains Council (IGC)) also publish daily updates for their members. As noted above, during COVID-19 several countries adopted this practice and also increased their reporting on supply and demand balances to stop panic buying. Multiple international organisations also started reporting on new policy developments as they were announced, thereby providing a global picture of countries' policies in real time. ${ }^{73}$ In some cases, policies in global markets were changing multiple times per day; Table 2 illustrates how the export policy decisions of two large exporting countries changed multiple times over a matter of weeks. In periods of emergency such as the COVID-19 pandemic, where the situation can change rapidly, publishing this information as soon as it becomes available is crucial for domestic and international markets to adapt.

\footnotetext{
${ }^{71}$ In particular, supply and demand information from the following three sources is published: FAO-AMIS, International Grains Council (IGC), and United States Department of Agriculture (USDA).

${ }^{72}$ Geoglam (2020), Crop Monitor for Early Warning, No. 50, 4 June, accessible at https://cropmonitor.org/documents/EWCM/reports/EarlyWarning CropMonitor 202006.pdf.

${ }^{73}$ For example, regular updates on policy developments could be found on the websites of IFPRI (https://public.tableau.com/profile/laborde6680\#!/vizhome/ExportRestrictionsTracker/FoodExportRestrictionsTracker ?publish=yes), ITC (https://macmap.org/en/COVID19), and WTO (https://www.wto.org/english/tratop e/COVID19 e/COVID19 e.htm).
} 
Table 2. Timeline of export restriction decisions on rice in Viet Nam and grains in Russia

\begin{tabular}{|c|c|}
\hline Country & Policy developments related to export restrictions \\
\hline Viet Nam & $\begin{array}{l}25 \text { March 2020: Introduces export ban on rice until } 28 \text { March } 2020 \text {. } \\
30 \text { March 2020: Traders report that rice export ban has not yet been lifted. } \\
1 \text { April 2020: Replaces rice export ban with export quota set at } 400000 \text { tonnes for April and for May. } \\
15 \text { April 2020: Announces that } 400000 \text { tonnes will be exported in April and that the export quota policy for May will be } \\
\text { revisited. } \\
22 \text { April 2020: Increases rice export quota for April from } 400000 \text { tonnes to } 500000 \text { tonnes to accommodate cargoes } \\
\text { transported to ports prior to export ban introduced } 25 \text { March } 2020 \text {. } \\
28 \text { April 2020: Announces that it will fully resume rice exports from } 1 \text { May } 2020 \text {. }\end{array}$ \\
\hline Russia & $\begin{array}{l}20 \text { March 2020: Introduces ten-day export prohibition on grains. } \\
24 \text { March 2020: Cancels export prohibition on grains. } \\
31 \text { March 2020: Eurasian Economic Union (EAEU) announces prohibition on the export of a number of basic foodstuffs } \\
\text { from the customs territory of the EAEU (including onions, garlic, turnips, rye, rice, buckwheat, millet, cereals, wholemeal } \\
\text { and granules from cereal grains, peeled buckwheat, prepared foods from buckwheat, crushed and uncrushed soybeans } \\
\text { and sunflower seeds) to enter into force } 12 \text { April } 2020 \text { and last until } 30 \text { June } 2020 \text {. } \\
1 \text { April 2020: Introduces a grain export quota of } 7 \text { million tonnes for the period April-June. The quota does not apply to } \\
\text { countries of the Eurasian Economic Union. } \\
12 \text { April 2020: EAEU export prohibition enters into force. } \\
26 \text { April 2020: Announces that grain export quota has been reached and that grain exports will be suspended until } 1 \text { July } \\
2020 \text {. } \\
1 \text { June 2020: EAEU amends its export prohibition to allow for exports of soybeans (crushed or uncrushed) from the customs } \\
\text { territory of the EAEU starting from } 1 \text { June } 2020 \text { (amendment was published } 2 \text { June } 2020 \text { and entered into force on } 13 \text { June } \\
2020 \text { ). }\end{array}$ \\
\hline
\end{tabular}

Source: Agricultural Market Information System (AMIS).

\section{Continued investment in transparency and policy co-ordination is essential}

The agricultural sectors most affected by the COVID-19 outbreak are livestock, and perishable and high value products (Section 2). Even though the staple crops covered by the AMIS initiative have experienced - so far - fewer problems due to the pandemic, the AMIS initiative has both helped ensure that this is the case, and can provide valuable lessons that can be replicated in the wider agricultural and food sector.

In the face of future known risks such as climate change as well as unknown risks (e.g. renewed disruptions due to COVID-19), the role of AMIS in continuing to provide transparency in the market and policy situation of staple crops and to keep co-ordinating policy responses remains critical. The transparency afforded by AMIS is crucial to keep global markets working and to support the resilience of the food system in providing people around the world with affordable, nutritious food. 


\title{
5. COVID-19 and longer-term challenges for food systems
}

\begin{abstract}
Even before the outbreak of COVID-19, food systems were faced with a formidable "triple challenge" of simultaneously providing food security and nutrition to a growing global population, ensuring the livelihoods of millions of people working along the food chain from farm to fork, and ensuring the environmental sustainability of the sector. Yet policy efforts have not been moving in this direction, and global trade in agriculture and food remains highly distorted. COVID-19 has compelled policy makers to make urgent decisions to ensure food supply chains continue to function. However, it is also essential to continue investing in the long-term goal of resilient, sustainable and productive food systems. Ending inefficient and environmentally harmful support would free up resources for a more forward-looking policy package better able to address the triple challenge. The unanticipated shock of COVID-19 underscores the urgency of moving away from "business as usual".
\end{abstract}

\section{Introduction}

The COVID-19 pandemic is a global humanitarian crisis with tragic loss of life and enormous economic repercussions. At the beginning of April 2020, more than half of the global population was ordered to stay at home to prevent the spread of the virus. Unemployment soared as businesses were forced to close; some will never re-open. Food systems came under unprecedented stress, as discussed in the preceding sections.

Yet even before the outbreak of COVID-19, food systems were faced with a formidable "triple challenge" of simultaneously providing food security and nutrition to a growing global population, ensuring the livelihoods of millions of people working along the food chain from farm to fork, and ensuring the environmental sustainability of the sector. The world's population is expected to reach almost 10 billion in 2050 , requiring a significant increase in the production of affordable, healthy and nutritious food. Food systems are also essential to the livelihoods of millions of people, particularly in developing countries, working as farmers, fishers, and all along agro-food chains. Moreover, food systems are not only dependent upon sustainable natural resources, but are responsible for the vast majority of global land and water use, and are an important source of greenhouse gas emissions.

The manner in which food systems absorb, recover, adapt and transform in response to the shock of COVID-19 will shape their level of resilience and their ability to deliver on the longer-term triple challenge. Policies and approaches to address both the dramatic short-term shocks and to enhance long-term resilience are essential, and those that encourage global food systems rather than domestic selfsufficiency will be more effective at meeting the triple challenge.

\section{Food systems have made remarkable achievements, but much more needs to be done}

Food systems have made remarkable achievements since the 1960 s, including by contributing to a significant reduction in global undernourishment, and improvements in farm livelihoods and agricultural productivity. But the scale of past achievements is as remarkable as what remains to be done:

- The world population has grown from 3 billion in 1960 to about 7.5 billion today, and there is more food available per capita than ever before. Still, globally, hundreds of millions of people were undernourished even before the COVID-19 crisis, with an even greater number either overweight or obese.

- The process of technical and structural change has benefited many farm households who have been successfully absorbed in faster growing parts of the economy, while consumers have benefited from lower prices and high quality, nutritious food. At the same time, this process has put pressure on the incomes of farmers who are not able to compete and, in some countries, contributed to distress migration to urban areas.

- The tripling of agricultural production since 1960 has been achieved primarily through improved yields and productivity growth, with only modest overall change in agricultural area. Had those productivity gains not been realised, the consequences for human development and for the 
environment would have been devastating. Nevertheless, production growth has imposed stresses on soil and water resources, and emissions from food systems account for one-third of anthropogenic global greenhouse gas (GHG) emissions.

Notwithstanding these achievements, countries' policies with respect to the "triple challenge" remain weak in overall terms. Investments are needed to improve the resilience of food systems, not just to COVID-19, but also to the multitude of shocks that can affect the food and agriculture sector. Increased resilience is also essential if food security and livelihoods goals are to be met in the context of a changing climate and other environmental emergencies.

Yet, policy efforts have not been moving in this direction. Progress by many OECD countries in shifting towards better targeted and less distorting support measures - for example, measures with a greater focus on innovation or technical advice to farmers - has largely stalled. The OECD's annual agricultural policy monitoring exercise (covering 54 countries and $75 \%$ of global agricultural value-added) shows that, in 2018-20, these countries provided a total of USD 720 billion per year in support to their agricultural sectors. About three-quarters of this support, USD 540 billion per year, was transfers to individual producers. ${ }^{74}$ Much of this support is linked to production of specific products, which reduces the flexibility of farms and food systems to adapt to unexpected economic or production shocks, climate change, or even shifts in consumer preferences. Rather than aiding the livelihoods of smaller producers, support also tends to go predominantly to larger producers, and negatively affects producers in other countries. Lastly, such support can undermine food security by increasing domestic prices, creating price volatility and undermining global markets as a source of resilience by making it harder for supply shocks in one country to be compensated by production in others.

Indeed, global trade in agriculture and food remains highly distorted. Average applied tariffs for agricultural products in OECD countries in 2015 were $7.4 \%$ (with WTO bound rates of $28.7 \%$ ) in comparison to average applied tariffs for industrial products of $2.2 \%$ (and WTO bound rates of $11.2 \%$ ) for the same period. Tariff rate quotas, which are not permitted for other goods under global trade rules, still restrict imports of many agricultural products. ${ }^{75}$ With the fastest rates of population growth out to 2050 and associated growth in food demand set to come from Sub-Saharan Africa, a region struggling to raise low agricultural productivity, increased global food trade will be essential. Furthermore, changing climatic conditions will also alter what can efficiently be grown where, causing shifts in trade - or potentially the need for more trade.

COVID-19 has compelled policy makers to make urgent decisions to ensure food supply chains continue to function. But there is a need to ensure that short-term support measures do not become permanent, and that policies designed to contribute to long-term goals of resilient, sustainable and productive global food systems are reinforced, not undermined, by policy action during the crisis.

\section{Challenge 1: Ensuring food and nutrition security}

\section{Getting food to consumers requires well-functioning supply chains and social safety nets}

Food and nutritional security depends on production and trade, and requires well-functioning supply chains to make sure food is available where consumers are. Over the past few decades, global food availability has outpaced population growth, leading to increasingly affordable food. COVID-19 containment measures have disrupted food production and trade, although global food availability has held up remarkably well.

Even before the COVID-19 outbreak, hundreds of millions of people worldwide were undernourished as poverty, conflict and civil unrest undermined their access to food. The persistent problem of undernourishment underscores the fact that food production and trade are necessary but not sufficient to achieve food and nutrition security. The long-term, sustainable response requires further action to tackle poverty and, in a number of countries, conflict resolution; in the shorter-term, well-functioning social safety

\footnotetext{
74 These figures draw on the latest OECD (2021), Agricultural Policy Monitoring and Evaluation 2021: Addressing the Challenges Facing Food Systems, OECD Publishing, Paris, https://doi.org/10.1787/2d810e01-en and have been updated from the original brief.

75 See OECD Policy Brief, Measuring Distortions in International Markets: The Agriculture Sector, June 2019, https://issuu.com/oecd.publishing/docs/measuring distortions in internatio.
} 
nets are needed to ensure that the most vulnerable in society have access to food. Since the COVID-19 pandemic began, OECD countries have been implementing a range of policies to ensure food can get to consumers, and in particular the most vulnerable groups, such as low-income households, people with health conditions, and elderly citizens. In some cases, this has meant making sure that food is available where consumers are by alleviating supply chain bottlenecks and arranging the delivery of food parcels to the vulnerable. In other cases, it has meant providing financial safety nets so consumers can maintain access to food. For example, countries have been providing additional funding for existing food assistance programmes including for food banks, as well as extra money during school closures (including via electronic vouchers) for families of children who usually benefit from free or discounted meals at school. Some OECD countries have also temporarily loosened eligibility requirements for receiving domestic food assistance.

\section{Challenge 2: Protecting livelihoods}

\section{Policies to address livelihood impacts should help farmers and firms respond flexibly to changing conditions}

Impacts of measures to contain the virus rippled through economies, affecting livelihoods all along the food chain. These impacts are likely to hit farmers especially hard in regions where food production systems are more labour intensive (and hence more vulnerable to the reduced availability of farm labour) and where there may be less institutional capacity to cope with the health and subsequent economic shocks. Farmers in both developing and developed countries may also have lower off-farm income due to the pandemic.

Over the medium-to-longer term, shifts in consumer demand due to confinement measures may have sustained effects on patterns of food consumption. Reducing human contact will be high priority for consumers, who are likely to increasingly use click and collect, meal delivery, drive through, or curb-side delivery options. Even with the gradual relaxing of social distancing restrictions, there will likely be a sustained reduction in demand from food service providers, compounded by the negative impacts of travel restrictions on tourism and the cancellation of large sporting and cultural events. Demand for high value, specialised agricultural and fisheries products is also likely to remain depressed, as consumers reduce their household spending. These shifts in consumer demand will require many actors along the food supply chain to adapt or reinvent their business models, and some may never recover.

A first challenge is to provide necessary short-term support to affected producers in a way that ensures that basic productive capacity is not lost. But a second, equally important challenge is to avoid temporary measures to support livelihoods becoming entrenched, preventing the necessary adjustments and reducing long-term resilience of global food systems. Countries should assist actors along the food chain to deal with the short and medium term challenges without jeopardising long-term policy goals. For example, many countries are providing regular information to farmers, food processors and food retailers about best practices to protect health and safety of workers, as well as timely data about consumer purchasing trends. Some countries have implemented policies to support marketing activities by agri-food businesses, including website design, development of e-sales/marketing and on-line activities. Granting flexibilities on deadlines for applying for subsidy payments and providing information for cross-compliance payments can help reduce financial insecurity for farmers. Waiving licensing requirements to enable restaurants to operate takeaway businesses can provide opportunities for firms to develop alternative income sources by responding to shifts in consumer demand. These types of interventions allow firms to adapt flexibly to changing conditions and constraints. ${ }^{76}$

\footnotetext{
${ }^{76}$ For a discussion of policy responses to COVID-19, see OECD (2021), Agricultural Policy Monitoring and Evaluation 2021: Addressing the Challenges Facing Food Systems, OECD Publishing, Paris, https://doi.org/10.1787/2d810e01en
} 


\section{Challenge 3: Environmental sustainability}

\section{COVID-19 pressures should help reinforce efforts to address long-term sustainability challenges}

Given the urgency to address the COVID-19 public health crisis, there is a risk that environmental policies are weakened or abandoned. But this would be a costly mistake. Food systems generate significant environmental pressures, both in local ecosystems (such as water pollution caused by excessive fertiliser use) and at the global level (notably through their contribution to climate change). As noted above, food systems account for one-third of anthropogenic GHG emissions; most of these emissions occur at the agricultural production stage or through land use changes. Agriculture also accounts for the vast majority of global water use, and uses up to half of the world's ice-free land surface, far more than any other human activity. Land use change caused by expanding agricultural activity is also a major threat to biodiversity. Environmental sustainability is important in its own right, but it is also in the long-term interests of producers in global food systems, as climate shocks and climate-related disasters pose challenges to the sector's resilience and create vulnerabilities, which are set to eclipse those of COVID-19. ${ }^{77}$

Over the coming decades, as the world's population becomes more numerous and more prosperous, additional demand for food is expected to put even more pressure on the environment. Limiting the environmental impact of food systems will require reforming agricultural policies, in combination with efficiency gains. Poor policy choices stimulate inefficient input use, as when water for irrigation is delivered free of charge; many existing agricultural support policies exacerbate the environmental impact of agriculture; and agriculture has generally been exempt from efforts to mitigate climate change. Moreover, productivity growth rates have fallen and remain well below potential, in part due to reduced public investments in agricultural R\&D in high-income countries. While progress has been made in several dimensions of agricultural sustainability, environmental pressures remain high.

While COVID-19 presented immediate challenges for food systems, efforts to invest in their resilience going forward should not only take account of the wide range of risks faced by the sector, but also the need to invest in making the sector more sustainable. This includes taking the opportunity to reform existing policies that jeopardise sustainability and reduce resilience; to revisit current resilience toolkits for farmers faced with shocks to ensure they promote sustainable practices going forward; and ensure that food systems are able to produce food where it can be done most efficiently and with the least damaging environmental impact. ${ }^{78}$ Action now should reinforce, and not distract policy makers from, the urgent task of investing in the long-term sustainability of food systems.

\section{Conclusion}

\section{Transforming food systems: Towards policies that enable increased productivity, sustainability, and resilience}

There is an opportunity today to reinvigorate reform ambitions. As result of the COVID-19 crisis, governments have the opportunity to pursue progressive agendas in global food systems. Ending inefficient and environmentally harmful support would free up resources for investments to address the triple challenge more effectively. By adopting a policy package that includes investments in technological development and regulatory reform, governments can create conditions supporting productive, sustainable and resilient food systems able to withstand future shocks. The unanticipated shock of COVID-19 underscores the urgency of a shift from 'business as usual' policies to a more forward- looking policy package for food systems.

\footnotetext{
77 See OECD (2020), "From Containment to Recovery: Environmental Responses to the COVID-19 Pandemic", OECD Policy Responses to Coronavirus (Covid-19), 20 April 2020, http://www.oecd.org/coronavirus/policy-responses/fromcontainment-to-recovery-environmental-responses-to-the-covid-19-pandemic-92c49c5c/.

${ }^{78}$ For a detailed discussion of policy options to strengthen resilience, see OECD (2020), Strengthening Agricultural Resilience in the Face of Multiple Risks, OECD Publishing, Paris, https://doi.org/10.1787/2250453e-en.
} 


\section{OECD FOOD, AGRICULTURE AND FISHERIES PAPERS}

This report brings together insights from OECD work on COVID-19 on food systems and was prepared for publication by the OECD Secretariat.

This report, as well as any data and any map included herein, are without prejudice to the status of or sovereignty over any territory, to the delimitation of international frontiers and boundaries and to the name of any territory, city or area.

The statistical data for Israel are supplied by and under the responsibility of the relevant Israeli authorities. The use of such data by the OECD is without prejudice to the status of the Golan Heights, East Jerusalem and Israeli settlements in the West Bank under the terms of international law.

Comments are welcome and can be sent to tad.contact@oecd.org. 